NBER WORKING PAPER SERIES

\title{
PRACTICAL MONETARY POLICY: EXAMPLES FROM SWEDEN AND THE UNITED STATES
}

\author{
Lars E.O. Svensson \\ Working Paper 17823 \\ http://www.nber.org/papers/w17823 \\ NATIONAL BUREAU OF ECONOMIC RESEARCH \\ 1050 Massachusetts Avenue \\ Cambridge, MA 02138 \\ February 2012
}

\begin{abstract}
A previous version of this paper was prepared for the Fall 2011 issue of Brookings Papers on Economic Activity. The views expressed here are my own and are not necessarily shared by the other members of the Riksbank's Executive Board or the Riksbank's staff. I am grateful for helpful comments from and discussions with Hanna Armelius, Claes Berg, Alan Blinder, Bernard Dumas, Karolina Ekholm, Jon Faust, Martin Flodén, Gabriela Guibourg, Jesper Hansson, Donald Kohn, Stefan Laséen, Andrew Levin, Jesper Lindé, Edward Nelson, Bengt Pettersson, Raghuram Rajan, Ulf Söderström, Ingvar Strid, Staffan Viotti, Karl Walentin, Jonathan Wright, Janet Yellen, my discussants Randall Kroszner and David Wessel and other participants in the Brookings Papers conference, and the editors. I thank, without implication, Riksbank staff members Magnus Åhl, Björn Andersson, and Mikael Apel for contributions to the paper. From May 2007, I serve a 6-year term as deputy governor of the Riksbank and one of the six members of the Riksbank's Executive Board. The views expressed herein are those of the author and do not necessarily reflect the views of the National Bureau of Economic Research.
\end{abstract}

NBER working papers are circulated for discussion and comment purposes. They have not been peerreviewed or been subject to the review by the NBER Board of Directors that accompanies official NBER publications.

(C) 2012 by Lars E.O. Svensson. All rights reserved. Short sections of text, not to exceed two paragraphs, may be quoted without explicit permission provided that full credit, including $(\mathbb{C}$ notice, is given to the source. 
Practical Monetary Policy: Examples from Sweden and the United States

Lars E.O. Svensson

NBER Working Paper No. 17823

February 2012

JEL No. E42,E43,E47,E52,E58

\begin{abstract}
In the summer of 2010, the Federal Reserve's and the Swedish Riksbank's inflation forecasts were below the former's mandate-consistent rate and the latter's target, respectively, and their unemployment forecasts were above sustainable rates. Given the mandates of the Federal Reserve and the Riksbank, conditions in both countries clearly called for policy easing. The Federal Reserve maintained a minimum policy rate, soon started to communicate possible future easing, and in the fall launched QE2. In contrast, the Riksbank started a period of rapid tightening. I examine the arguments that were raised in opposition to the Federal Reserve's easing, and those for the Riksbank's tightening. Although the Swedish economy subsequently performed better than expected, probably an important reason was that the market implemented much easier financial conditions than were consistent with the Riksbank's policy rate path. Without the policy tightening, performance would have been even better. The U.S. economy meanwhile performed worse than expected because of factors other than monetary policy. Without the policy easing, performance would have been even worse. Thus, the Federal Reserve appears to have followed its mandate in the summer of 2010, and subsequent adverse economic shocks contributed to weak performance of the U.S. economy. In contrast, the Riksbank appears to have deviated from its mandate, but favorable circumstances contributed to an economic outcome with better performance than might have been expected based on policy choices.
\end{abstract}

Lars E.O. Svensson

Sveriges Riksbank

SE-103 37 Stockholm

SWEDEN

and Stockholm University

and also NBER

lars.svensson@iies.su.se

An online appendix is available at:

http://www.nber.org/data-appendix/w17823 
In the spring of 2011, the Swedish economy was being called a "Pippi Longstocking economy" and a "tiger economy," reflecting high growth after a deep recession. ${ }^{1}$ Conditions in the U.S. economy seemed more problematic. One might think that the disparate performances of the Swedish and U.S. economies could be attributed to their respective monetary policies. I will argue that on the contrary, and perhaps surprisingly, in the summer of 2010, when forecasts for inflation (too low) and unemployment (too high) were similar in the two countries, the Riksbank's monetary policy, by starting a period of rapid policy rate increases, was not in line with its mandate. In contrast, the Federal Reserve kept the policy rate at its lower bound, soon started to communicate possible policy easing, and later launched QE2, the second round of quantitative easing. That the Swedish economy nevertheless grew faster than expected may largely be explained by the market implementing an actual yield curve that was lower than implied by the policy rate path, so that actual financial conditions were much more expansionary than the Riksbank intended. That the U.S. economy performed worse than expected is due to factors other than monetary policy.

This paper examines the actions of the Federal Reserve and the Riksbank in the summer of 2010 as examples of practical monetary policy. My starting point is that there is a substantial degree of consensus among central bankers and academics that the objective of an appropriate monetary policy framework is twofold: to stabilize inflation around a low level and to stabilize resource utilization around the highest sustainable level (Bernanke 2011d). The dual mandate of maximum employment and stable prices of the Federal Reserve, with its mandate-consistent inflation rate, and the flexible inflation targeting of the Riksbank, are both fully consistent with such a framework. There is no fundamental difference between the monetary policy frameworks of the two central banks, although their communications strategies are somewhat different. ${ }^{2}$

The Federal Reserve's dual mandate and the Riksbank's flexible inflation targeting both boil down to "forecast targeting" (Woodford 2007, Svensson 2011c), that is, choosing a policy rate path such that the corresponding forecasts for inflation and resource utilization "look good," in the sense that they best stabilize inflation around the inflation objective (the mandate-consistent rate or the target inflation rate) and resource utilization around its highest sustainable level. Thus, "looking good" means achieving an efficient trade-off between inflation stability and stable resource utilization. ${ }^{3}$

The forecasts for inflation and unemployment published by the Federal Open Market Committee (FOMC) and the Riksbank make it possible to assess whether they "look good"-more precisely, whether they look as good as possible, taking into account what policy actions are possible. What is possible in turn depends on restrictions such as the zero lower bound (ZLB), the ability to manage expectations of future policy rates and inflation, and the availability of unconventional policy tools such as the size and composition of the central bank's balance sheet.

In the summer of 2010, forecast inflation in both countries was too low relative to the central bank's objective, and forecast unemployment was too high relative to a sustainable unemployment rate. All else equal, such a configuration of forecasts calls for more expansionary policy, if that is possible. In the event, however, as mentioned the FOMC and the Riksbank chose very different policies. The FOMC maintained a target range for the federal funds rate of 0 to 25 basis points (bp) and effectively eased policy further by communicating possible future policy easing and, in the fall, launching QE2. The Riksbank instead embarked on a policy of rapid policy rate increases. 
Several arguments against the Federal Reserve's policy easing have been presented. These relate to concerns about higher inflation and the anchoring of inflation expectations, to uncertainty about the effect of the unconventional policy measures, to possible negative consequences of low policy rates for financial stability and investment allocation, to possible overestimation of the amount of slack in the economy, and to concerns about increased exposure of the Federal Reserve's balance sheet to possible capital losses. Some emerging-market policymakers have also expressed concern that the policy would result in increased capital inflows into their countries, generating bubbles and other negative impacts. I will argue that none of these arguments are convincing, and thus that the Federal Reserve's policy easing was in line with its mandate.

Several arguments for the Riksbank's policy tightening have likewise been presented. One argument focuses on the stabilization of economic growth rather than of resource utilization, another seems to call for mechanical revision of the policy rate path as outcomes diverge from forecasts, a third advocates using the policy rate to limit increases in household debt and housing prices, and a fourth calls for normalizing the policy rate to prevent unspecified future financial imbalances. I will argue that these arguments, too, are not convincing, and thus that the Riksbank's policy tightening was not consistent with its mandate.

I will argue further that the Riksbank's action deviated from its mandate not only ex ante, taking into account only the information available at the time, but also ex post, taking into account information that became available later. As I have argued elsewhere (Svensson 2011b), evaluation ex ante is more relevant when assessing the quality of policy decisions, whereas evaluation ex post, although still interesting, to a considerable extent means assessing whether the policymaker was lucky or unlucky. By July 2011, a year after the tightening began, the Swedish economy had performed better than had been anticipated. Growth had been higher and unemployment had fallen more than forecast in the summer of 2010. Does this better-than-expected performance mean that the policy tightening begun in the summer of 2010 was in line with the Riksbank's mandate? Put differently, had the better future performance of the Swedish economy been known at the time, would it have been in line with the mandate to initiate policy tightening? My answer is no. The reason is that in July 2011, inflation and the inflation forecast, although higher, were still too low, and unemployment and the unemployment forecast, although lower, were still too high. A more expansionary policy in the summer of 2010 would have resulted in an even better outcome, with inflation higher and unemployment lower.

Why did the Swedish economy perform better than had been anticipated in the summer of 2010 ? The Riksbank itself (Sveriges Riksbank 2011c) mentions higher-than-expected exports, domestic demand, and productivity. But another possible explanation, not mentioned in that document, is that actual financial conditions were substantially more expansionary than the intended financial conditions. That is, the actual market term structure of interest rates was more expansionary than that which would have been consistent with a credible policy rate path and normal term premiums. For instance, from the beginning of 2010 until July 2011, Swedish 5-year interest rates were on average about 85 bp lower than the average consistent with a credible policy rate path and normal term premiums. Thus, the Swedish economy may have benefited from the market effectively implementing a more expansionary policy than what the Riksbank intended.

Three circumstances may have contributed to the Riksbank's choice of a high policy rate path. First, its forecast for foreign policy rates has consistently been too high, much above levels consistent with 
foreign yield curves and implied forward rates. All else equal, this implies an upward bias in the domestic policy rate path. Second, the outlook for potential output and estimates of past potential output were seen as having shifted downward considerably since the global financial crisis, even though the shock to the economy was an aggregate demand shock, in the form of a collapse of world demand for Swedish exports, and thus should have had little or no effect on future, let alone past, potential output. All else equal, this downward shift of the potential output forecast implies an upward bias in the estimate of resource utilization and thus in the policy rate path. Third, Sweden has undertaken substantial structural reforms over the last few years, which, studies indicate, have significantly lowered the sustainable unemployment rate. Yet the Riksbank in response has made only a small adjustment to its estimate of the sustainable rate, thus imparting another upward bias to the policy rate path. A lower forecast for foreign policy rates in line with market expectations, together with a higher estimated potential output and a lower estimated sustainable unemployment rate, would strengthen the case for more expansionary policy in Sweden.

The paper is organized as follows. Section I discusses the monetary policy framework in the United States and Sweden, section II shows how published FOMC and Riksbank forecasts can be used to analyze policy, and section III discusses the situation and policy decisions at the FOMC's and the Riksbank's meetings in the summer of 2010. Section IV scrutinizes arguments for the Riksbank's policy tightening, and section V scrutinizes arguments against the FOMC's policy easing. Section VI discusses the situation facing the Riksbank in July 2011, why the Riksbank's policy rate path was so high, and why the Swedish economy performed better than expected. ${ }^{4}$ Section VII presents some broader conclusions. Online appendixes contain further details. ${ }^{5}$

\section{The Monetary Policy Framework}

There is substantial consensus among central bankers and academics that an appropriate monetary policy framework has as its objective both price stability and real stability (Bernanke 2011d); more precisely, the objective is to stabilize both inflation around a low rate and resource utilization around the highest sustainable level. The mandates of the Federal Reserve and the Riksbank are both consistent with this. The Federal Reserve's dual objective of maximum employment and stable prices can be seen as stabilizing inflation around a mandate-consistent inflation rate and stabilizing employment around the highest sustainable employment rate. "Maximum employment" is in practice the same as the highest sustainable employment rate. The Riksbank's objective is likewise twofold: to stabilize inflation around the inflation target and resource utilization around the highest sustainable level. ${ }^{7}$

In practice, the dual mandate and flexible inflation targeting both amount to "forecast targeting" (Woodford 2007, Svensson 2011c): choosing a policy rate and a policy rate path (or, under special circumstances, using unconventional policy instruments) that best stabilize both the resulting inflation forecast around the objective and the resulting resource utilization forecast around a sustainable level. This can be made more precise and operational by specifying a measure of inflation (PCE or core PCE inflation in the U.S. case, CPIF inflation in Sweden; both are defined below) and a measure of resource utilization (such as the gap between the unemployment rate and an estimate of the sustainable rate, the steady-state equilibrium unemployment rate), and by specifying a quantitative measure of stability, that is, a measure of to what extent a particular forecast of inflation or resource utilization stabilizes inflation or resource utilization. 
A suitable measure of stability is the mean squared gap: the mean over the forecast period of the squared deviation of the mean forecast from the target or sustainable level (the sum of squared deviations can be used instead). ${ }^{8}$ Specifying weights on the stability of resource utilization and on the stability of inflation then results in a standard quadratic loss function (with no discounting). One can go further and discuss to what extent mean forecast targeting (relying on certainty equivalence and hence only on mean forecasts) is still a good approximation when there is model uncertainty, multiplicative uncertainty, and so on. In practice there is usually insufficient information to know whether a policy should be more or less aggressive than the certainty-equivalent one, so the certainty-equivalent policy is still warranted (the main exception is the nonlinearity caused by the lower bound on nominal interest rates).

I have come to the conclusion that the gap between the unemployment rate and an estimate of the sustainable rate is the best measure of resource utilization. The main reason is that the alternative of using the output gap requires estimating potential output, and during my period at the Riksbank I have become more skeptical about measures of potential output. Estimating the sustainable unemployment rate is less difficult and carries less risk of big mistakes. One can thus have a more open and transparent discussion about the sustainable unemployment rate than about potential output. I discuss some problems relating to the Riksbank's measures of potential output in section VI. ${ }^{9}$

Also important is to distinguish between using measures of resource utilization as indicators of inflationary pressures and using them as target variables. For the former, it is the gap between the unemployment rate and any short-run NAIRU or equilibrium unemployment rate that is relevant. For use as a target variable, however, I am convinced that the relevant measure is the gap between the actual unemployment rate and the sustainable rate (Blanchard and Gali 2010). ${ }^{10}$ Using instead a short-run NAIRU as a target and stabilizing unemployment around it effectively implies introducing inflation smoothing as an objective, which makes little sense. (This is discussed further in online appendix A1.) This is not to say that short-run slack in the economy should be disregarded. Short-run slack does have an impact on inflation and the inflation forecast, but it is only for that analysis that it matters.

\section{Using FOMC and Riksbank Forecasts to Analyze Policy}

Published Riksbank forecasts for inflation, various resource utilization measures, and the policy rate make it easy to describe the economic outlook in Sweden and to assess whether easier or tighter policy would better stabilize inflation and resource utilization or make them worse. The published FOMC participants' projections for inflation, GDP growth, and unemployment create considerable scope to do the same for the United States. Indeed, at Chairman Ben Bernanke's press conferences after the policy meetings, these projections take center stage. As he noted in his opening remarks at the press conference on April 27, 2011:

The Committee's economic projections provide important context for understanding today's policy action as well as the Committee's general policy strategy. Monetary policy affects output and inflation with a lag, so current policy actions must be taken with an eye to the likely future course of the economy. Thus the Committee's projections of the economy, not just current conditions alone, must guide its policy decisions. The lags with which monetary policy affects the economy also imply that the Committee must focus on meeting its mandated objectives over the medium term, which can be as short as a year or two but may be longer, depending on how far the 
economy is initially from conditions of maximum employment and price stability. (Bernanke 2011b, pp. 4-5)

The FOMC's projections are usually presented in terms of an interval, called the central tendency, where the three highest and the three lowest projections for each year have been excluded. However, the individual participants' projections are presented in sufficient detail that a smaller interval for the median of the projections can be identified. The midpoint of that interval can then be used as a reasonable point forecast of the FOMC. Further, the median of the different participants' longer-run projections for inflation can, by the median-voter theorem, be interpreted as the result of a hypothetical majority vote among them about the FOMC's mandate-consistent inflation rate, and the median of the longer-run projections for unemployment as the result of such a vote about the FOMC's estimate of the sustainable unemployment rate. ${ }^{11}$

As noted above, there are good reasons why the forecasts used to guide monetary policy should be mean forecasts, not mode or median forecasts. Mean forecasts have the attractive property that they are "risk adjusted," in the sense of being the probability-weighted sum of upside and downside risks; that is, the risks should already be incorporated into the mean forecast and need not be accounted for separately. For instance, a higher probability of a low outcome will reduce the mean outcome. The Riksbank forecasts are, since February 2007, intended to be mean forecasts, but the FOMC forecasts are mode forecasts. However, I will assume that the probability distributions around FOMC forecasts are sufficiently close to unimodal and symmetric that the difference between the mode and the mean does not matter. (Online appendix A2 discusses mean, mode, and median forecasts in more detail.)

Each FOMC participant's projections of inflation, unemployment, and growth are based on that participant's assessment of "appropriate monetary policy," defined as "the future path of policy that each participant deems most likely to foster outcomes for economic activity and inflation that best satisfy his or her interpretation of the Federal Reserve's dual objectives" (FOMC 2010b). Thus, behind each participant's projection is a policy rate projection. Those projections are not published, however. That is, the intended monetary policy and financial conditions are not directly available. Instead, only the actual financial conditions, in the form of the market term structure of interest rates, are available. In contrast, for the Riksbank both intended and actual financial conditions are directly available.

As examples of practical monetary policy, I will look at the policy decisions by the two central banks in the summer of 2010: that of the FOMC at its June 22-23 meeting, announced on June 23, and that of the Riksbank at its June 30 meeting, announced on July 1 (which I therefore call the June/July meeting). For the Riksbank I will also look at the policy decision a year later, on July 4, 2011, announced on July 5.

\section{The Situation in June 2010}

Figure 1 shows, for the United States, realized PCE inflation and realized core PCE inflation from 2000 through 2010Q1, the last full quarter for which data were available for the FOMC June 2010 policy meeting. (PCE inflation is the annual rate of change in the price index for personal consumption expenditures; core PCE inflation uses the PCE price index excluding food and energy.) The extensions of those series beyond 2010Q1 represent the FOMC forecasts for the two measures at that meeting, 
constructed as the median of the participants' projections as reported in FOMC (2010b). For Sweden, figure 1 shows realized and forecast CPIF inflation (the annual change in the consumer price index excluding direct effects on the CPI of changes in mortgage rates) from the Riksbank's June/July 2010 meeting. ${ }^{12}$

The central tendency of the FOMC participants' longer-run PCE projections is reported as 1.7 to 2.0 percent, but the median actually falls in the upper range of this interval, or more precisely, between 1.85 and 2.05 percent, with the midpoint at 1.95 percent (FOMC 2010b). I will assume here that this number, rounded to 2 percent (using unbiased rounding), is the Federal Reserve's mandate-consistent inflation rate. The Riksbank's inflation target is also 2 percent. As the figure shows, both central banks were forecasting inflation below the objective, except at the end of the forecast period for the Riksbank. These forecasts alone therefore indicate that more expansionary policy, if possible, was in line with their mandates. ${ }^{13}$

Figure 1. Inflation, Realized and June/July 2010 Central Bank Forecasts, Sweden and United States Percent per year

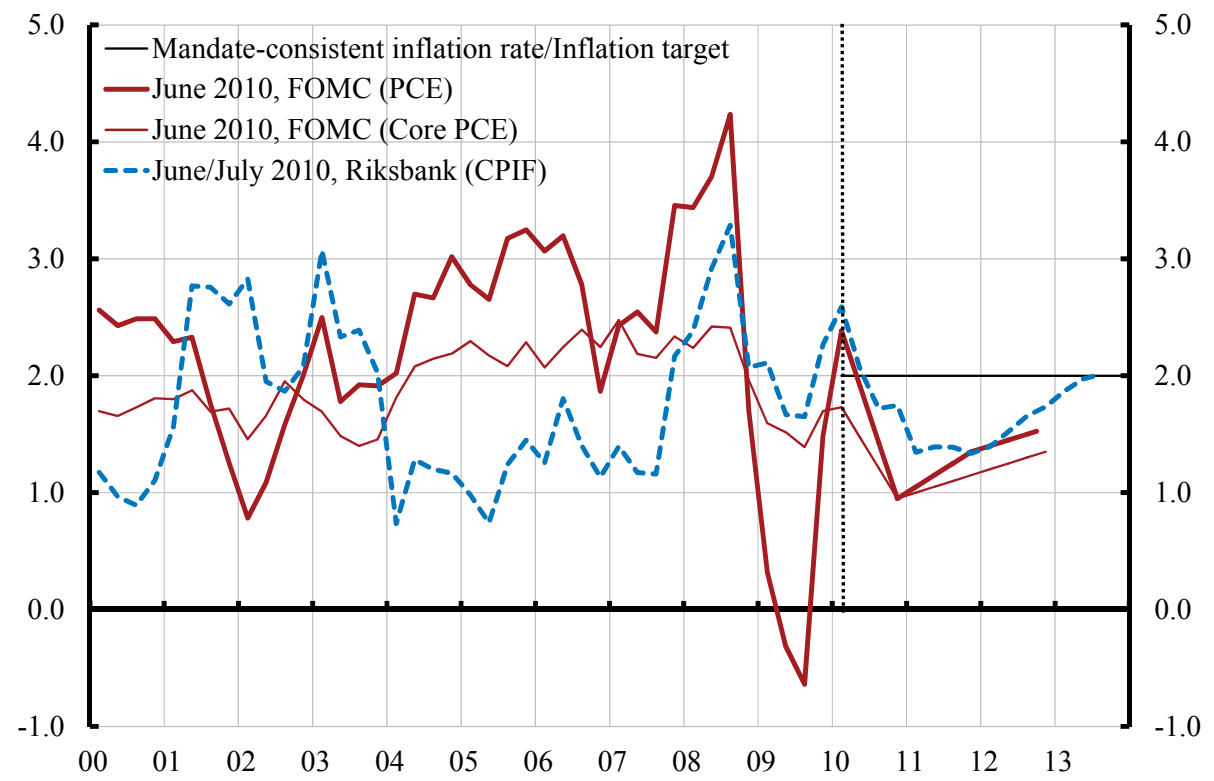

Sources: The Bureau of Economic Analysis, the FOMC, Sveriges Riksbank, and Statistics Sweden. Note: The vertical line indicates 2010Q1, the last quarter for which inflation outcomes were available for the FOMC's and the Riksbank Executive Board's June/July 2010 meetings. The extensions to the right of the vertical line are the forecasts announced after those meetings. The horizontal line shows the median of FOMC participants' longer-run projections of PCE inflation as of the June 2010 meeting, rounded from 1.95 percent. The Riksbank's inflation target is also 2 percent.

Figure 2 shows the two countries' realized and forecast unemployment rates at the same policy meetings. Also shown is the median of the FOMC participants' projections of the longer-run unemployment rate, which I take as the FOMC's estimate of the sustainable unemployment rate. The median falls in the interval from 4.95 to 5.15 percent, with the midpoint at 5.05 percent, which I round to 5.1 percent. ${ }^{14}$ For Sweden, a graph in the Riksbank's October 2010 Monetary Policy Report (figure B23, p. 61) shows an estimate of the sustainable unemployment rate of 6.5 percent from 2010 onward. I 
therefore use that as the sustainable unemployment rate as of the June/July meeting. Both the U.S. and the Swedish forecasts are above the sustainable rate, meaning that forecast resource utilization was too low, thus also indicating that more expansionary policy, if possible, was in line with their mandates.

In such a situation, the simple criterion suggested by Deputy Governor of the Norges Bank Jan Qvigstad (2005) applies: the forecasts for inflation and resource utilization should not both be too low, nor should both be too high. If both are too low, as in this case, easier policy would better stabilize both inflation and resource utilization.

Figure 2. Unemployment Rate, Realized and June/July 2010 Central Bank Forecasts, Sweden and United States

Percent

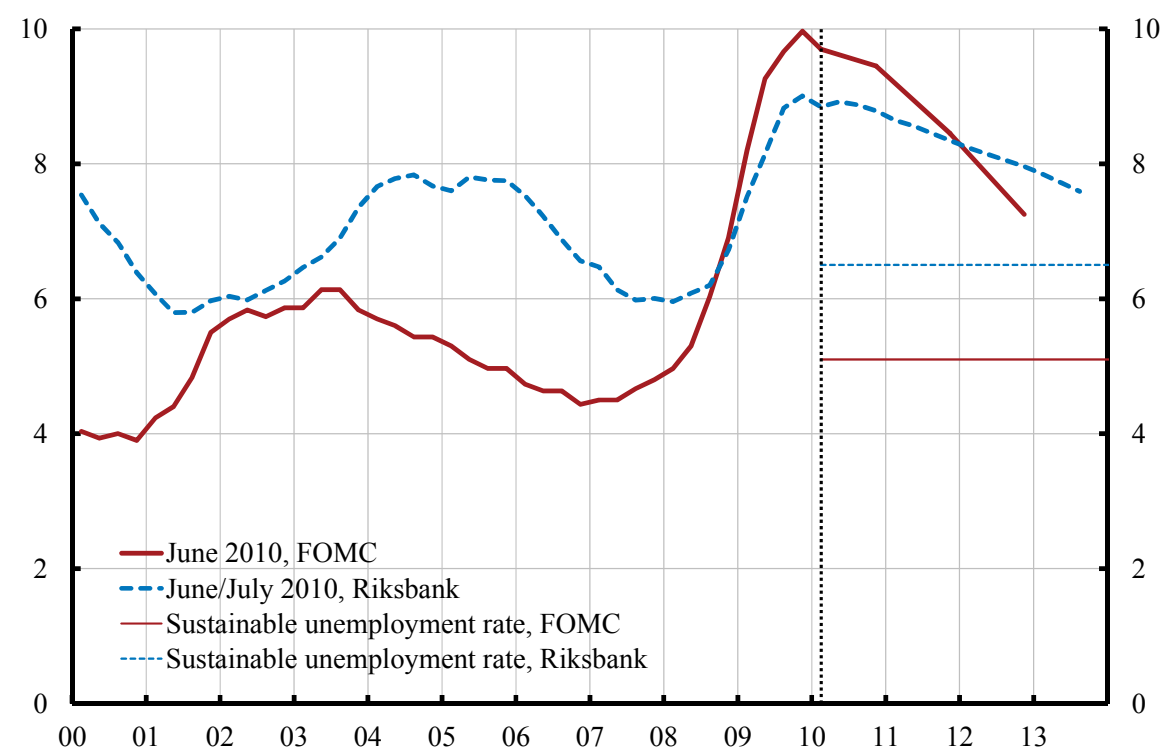

Sources: The Bureau of Labor Statistics, the FOMC, Sveriges Riksbank, and Statistics Sweden.

Note: The vertical line indicates 2010Q1, the last quarter for which unemployment rate outcomes were available for the FOMC's and the Riksbank Executive Board's June/July 2010 meetings. The extensions to the right of the vertical line are the forecasts announced after those meetings. The horizontal red solid line is the median of FOMC participants' projections of the longer-run unemployment rate, as of the June 2010 meeting, rounded from 5.05 percent. The horizontal blue dotted line is the Riksbank's estimated sustainable unemployment rate.

The FOMC (2010a) announced after its June meeting that it "will maintain the target range for the federal funds rate at 0 to $1 / 4$ percent and continues to anticipate that economic conditions, including low rates of resource utilization, subdued inflation trends, and stable inflation expectations, are likely to warrant exceptionally low levels of the federal funds rate for an extended period." In August it announced that it would keep the Federal Reserve's holdings of securities constant at their current level by reinvesting principal payments from agency debt and agency mortgage-backed securities in longer-term Treasury securities. After speeches by Chairman Bernanke (2010a, 2010b) in August and September in which he discussed additional policy measures, in November the FOMC launched QE2, announcing that it intended to purchase a further $\$ 600$ billion of longer-term Treasury securities by the end of 2011Q2. 
The Riksbank, in contrast, raised its policy rate, the repo rate, from $25 \mathrm{bp}$ to $50 \mathrm{bp}$ after its June/July meeting, launching a period of rapidly rising policy rates. In doing so it announced that "the Swedish economy is developing strongly following the severe downturn. The repo rate now needs to be raised gradually towards more normal levels to attain the inflation target of 2 per cent and to ensure stable growth in the real economy." Two members of the Riksbank's Executive Board, Deputy Governor Karolina Ekholm and I, dissented. ${ }^{15}$

Figure 3 shows the federal funds rate before and the term structure of U.S. interest rates after the FOMC's June 23 announcement; the term structure here is measured by market forward rates adjusted for normal forward term premiums (assumed to be $1 \mathrm{bp}$ per month). The forward rate curve indicates that the market expected the federal funds rate to remain at its very low level at least for another year. For Sweden the figure shows the repo rate before and the term structure of interest rates (likewise measured by adjusted forward rates) after the Riksbank's July 1 announcement. The figure also shows the announced policy rate path. Note that the forward rate curve is much lower than the policy rate path, indicating that the market expected the Riksbank to raise the policy rate at a much slower pace.

Figure 3. Policy Rates, Policy Rate Expectations, and Riksbank Policy Rate Path, June/July 2010, Sweden and United States

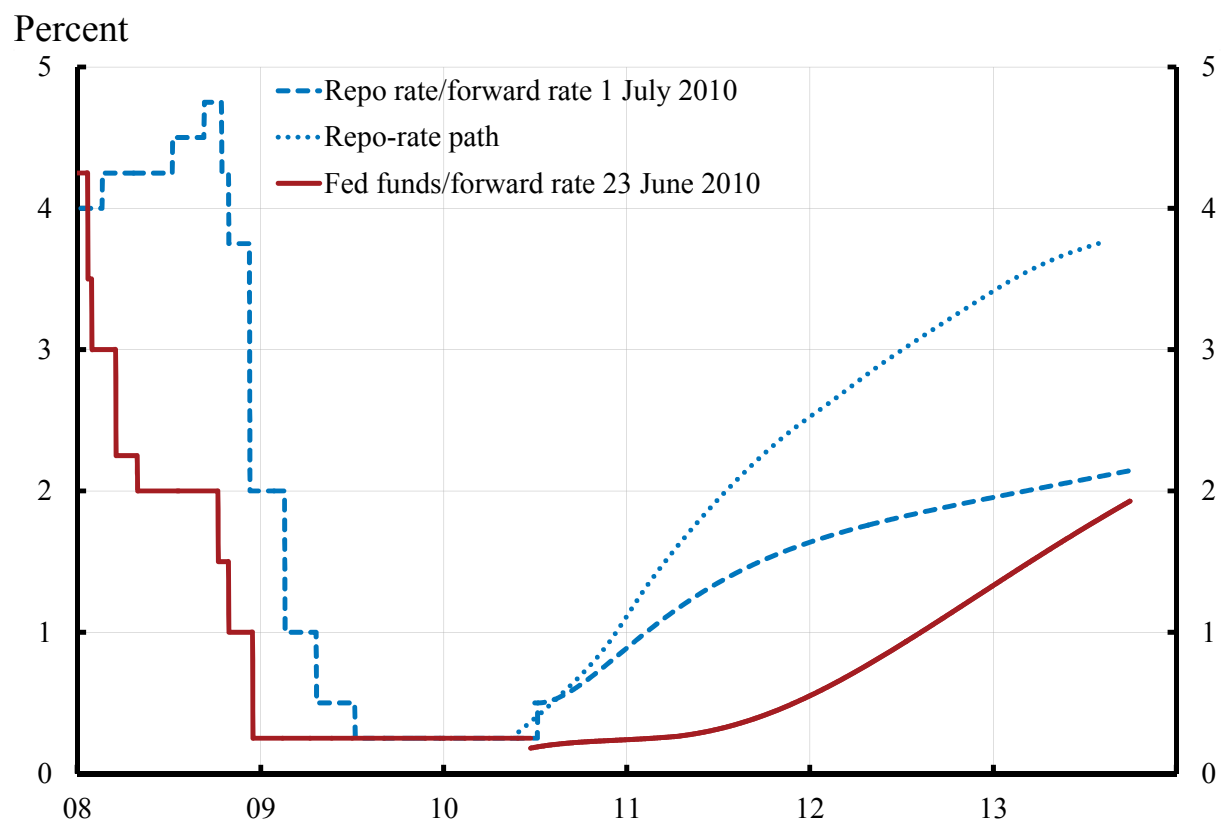

Sources: Reuters EcoWin and Sveriges Riksbank.

Note. Forward rates are adjusted for normal forward term premiums (assumed to be $1 \mathrm{bp}$ per month).

Thus, for Sweden, figure 3 shows both the actual financial conditions (market expectations of the future repo rate) and the Riksbank's intended financial conditions (the published repo rate path). For the FOMC, the figure shows only the actual financial conditions (market expectations of the future federal funds rate). We do not know what policy rate path corresponds to the median of the FOMC participants' views of "appropriate policy." Nor do we know whether appropriate policy for some participants included at least some of the QE that the Federal Reserve implemented in the fall. ${ }^{16}$ 
Figure 3 highlights that, for the Riksbank, more expansionary policy was clearly possible. Obviously, the published policy rate path could have been shifted down. This should have had an impact on market expectations and shifted down the term structure of interest rates, in particular if the policy rate path were shifted down to or below the forward rate curve. The FOMC, however, was clearly more constrained. The target range for the federal funds rate was 0 to $25 \mathrm{bp}$, and the zero lower bound (ZLB) was effectively binding. Arguably, the funds rate could have been lowered to zero, and a zero interest rate could have been paid on reserves (Bernanke 2010a, 2011a). The FOMC could also have announced that it might keep the federal funds rate low for longer than the market was expecting, and possibly shifted the term structure of interest rates down further (Bernanke 2010a, 2010b, Yellen 2011c). Indeed, just over a year later, in its August 9, 2011, statement, the FOMC extended the period of low federal funds rates, announcing that it anticipated that economic conditions were likely to warrant "exceptionally low levels for the federal funds rate at least through mid-2013." However, we do not know how successful such a move would have been in June 2010. Finally, the FOMC could have managed its balance sheet so as to reduce longer-term interest rates, by reducing term premiums. Some simulations published later (Chung and others 2011, Cúrdia and Ferrero 2011, Fuhrer and Olivei 2011) indicate that such action would have had a significant effect, and in the end, this is what the FOMC opted for in the fall. As was apparent from the reaction of some politicians and the media, the FOMC then faced substantial political resistance to more expansionary policy. I find it difficult to judge the overall extent of economic and political constraints on the FOMC. ${ }^{17}$

\section{Arguments for the Riksbank's Policy Tightening}

The argument against the Riksbank's policy tightening in June/July 2010 is straightforward. Given the Riksbank's objectives, forecast inflation was too low, and forecast unemployment was too high. Easier policy would have led to better attainment of both inflation and resource utilization objectives. Several arguments for the Riksbank's policy tightening are presented in the minutes of that meeting (Sveriges Riksbank 2010b) and were presented at other policy meetings. I group them here into four main arguments: ${ }^{18}$

— the growth stabilization argument

- the revision argument

- the household debt and housing prices argument

- the normalization argument.

Except for the second, all four are essentially arguments for why policy should, at least on this occasion, be based on something other than the forecasts of inflation and resource utilization.

\section{IV.A. The Growth Stabilization Argument}

Some arguments for tightening seem to concern the stabilization of economic growth rather than of resource utilization. Recall that the Riksbank's July 2010 announcement stated that "[ $t]$ he Swedish economy is developing strongly following the severe downturn. The repo rate now needs to be raised gradually towards more normal levels to attain the inflation target of 2 per cent and to ensure stable growth in the real economy" (emphasis added). This gives the impression that monetary policy was directed toward stabilizing growth rather than the level of resource utilization. However, the Swedish word translated here as "growth" is utveckling, which is often translated as "development" or, in this context, as "performance." Therefore, the sentence above should arguably have ended "to ensure the 
stable performance of the real economy." Still, it is clear that the announcement emphasizes the change in the real economy rather than the level of resource utilization. And, as far as I know, no objections were raised to translating utveckling as "growth."

Furthermore, the headings in the slide presentation at the press conference on July 1, 2010, read as follows: "Swedish economy developing strongly," “...despite fiscal problems in Europe," "Limited impact on the financial markets," "The global recovery is continuing," "Broad upturn in Swedish economy," "The upturn is continuing," "Employment is increasing," "Lower unemployment ahead," "Inflation in line with target," "Interest rate increased from low level," "A forecast, not a promise," and again, as clearly the main message, "Swedish economy developing strongly." It seems fair to say that these headings reinforce the impression that the Riksbank was emphasizing the growth in the economy and the change in resource utilization rather than the level of resource utilization.

Figure 4, which shows the level of Swedish GDP over the recent period, and figure 5, which shows the GDP growth rate, give rather different impressions. In the summer of 2010, both realized and forecast output was quite low. Realized growth in 2010Q1 was high, 6 percent at an annual rate, but the forecast was not much above normal. Stabilizing growth at that low level of output would seem to amount to prolonging the recession. Stabilizing resource utilization would imply a very different policy.

Figure 4. GDP, Realized and Forecast, and Potential GDP, Sweden Index, 2007Q4 realized GDP $=100$

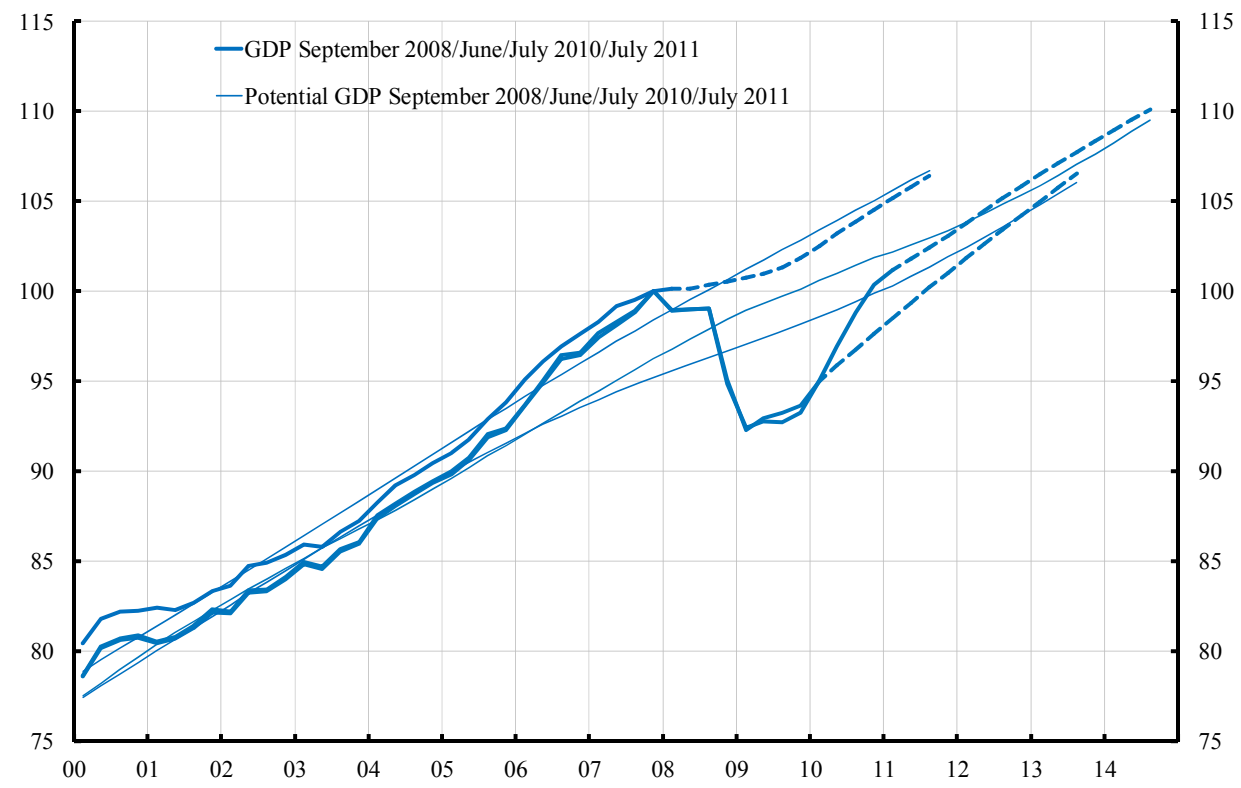

Sources: Sveriges Riksbank and Statistics Sweden.

Note: For each date, the thick solid line represents the most recently available estimates of realized GDP, the dashed line the Riksbank's GDP forecast, and the thin solid line the Riksbank's then-current estimate and forecast of potential GDP (as of September 2008, June/July 2010, and July 2011).

The Riksbank's thrice-yearly Monetary Policy Report has also traditionally emphasized growth rather than the level of resource utilization, at least when it comes to the figures. The first four main graphs in each report show the repo rate path and the forecasts of GDP growth, CPI inflation, and CPIF 
inflation. In the July 2010 report, forecasts of employment, unemployment, and resource utilization do not appear until figure 18, on page 15, and later. It is less than obvious from that report that inflation and resource utilization are supposed to be the two target variables of the Riksbank.

My experience from practical monetary policy is that there is often considerable ambiguity and confusion between growth and levels of the real economy. I maintain that the level of resource utilization, not the growth rate, should be the relevant target variable for monetary policy, in order to best full the mandate. In particular, stabilizing growth after a big fall in output and a rise in unemployment will prolong the period of low resource utilization. Higher than normal growth is then warranted to return to the sustainable level of resource utilization.

Figure 5. GDP Growth, Realized and Forecast, Sweden

Annualized quarterly growth, percent

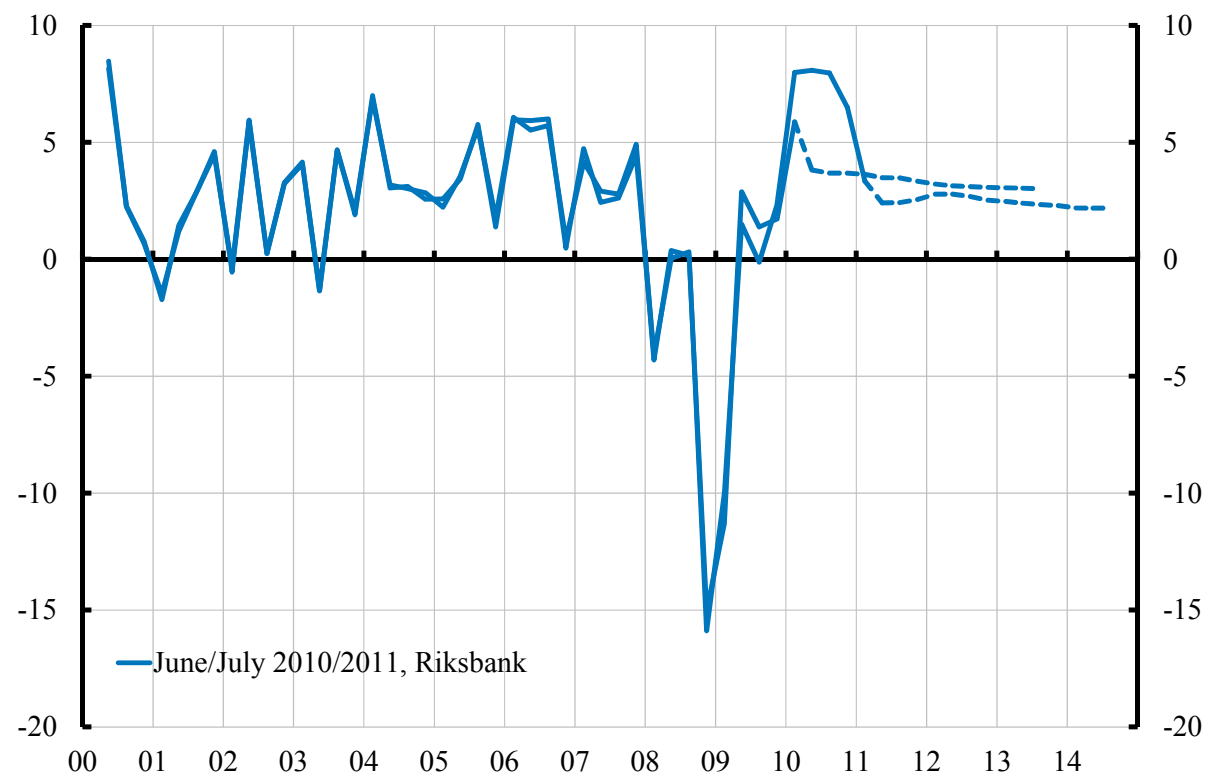

Sources: Sveriges Riksbank and Statistics Sweden

Note: For each date, the solid line represents the most recent available estimates of realized GDP growth (annualized), and the dashed line the Riksbank's GDP growth forecast.

\section{IV.B. The Revision Argument}

The outlook for the real economy at the June/July 2010 meeting was a bit better than had been projected at the previous meeting, in April 2010. Realized GDP growth was a bit higher, and realized unemployment a bit lower, than had been anticipated. This was mentioned as a reason for tightening policy. The argument seems to be that if the outcome for the real economy or inflation, or both, is higher (or lower) than anticipated, policy should be tightened (or eased) a bit. Of course, this assumes that previous policy was optimal. If previously the policy was at a corner solution - for instance, with a binding ZLB - this conclusion does not follow. Unfortunately, the Riksbank's communication was not clear about whether the period from April 2009 through April 2010, when the policy rate was 25 bp, was one of a binding effective lower bound or not (Svensson 2010a). Furthermore, since policy is never perfect, mechanically applying the above argument can mean that error is added to error, and policy could 
drift away from its optimum like a random walk. This can be avoided if policy instead is checked against and is mainly based on forecasts of levels of inflation and resource utilization. ${ }^{19}$

\section{IV.C. The Household Debt and Housing Prices Argument}

Several Riksbank board members at several policy meetings have expressed worries about an increasing ratio of household debt to disposable income - in June/July 2010 it was about 170 percentand about rising housing prices. The suggestion is that a policy rate increase would beneficially dampen the growth of household indebtedness and of housing prices. This raises two questions: first, whether household debt and housing prices present a problem for the macroeconomy or financial stability, and second, if they do, whether the policy rate is a suitable instrument to address the problem or whether there are other, better instruments.

On the first question, household debt is not considered to be a problem for financial stability in Sweden. The likelihood that Swedish banks would suffer any losses from mortgages is very small. The reason is that mortgages are full recourse, credit reviews are thorough (in part because mortgages are not securitized but stay with the initiating mortgage institution), and households' capacity to repay debt is good. Not even during the severe crisis in the early 1990s did mortgage issuers incur any substantial losses from mortgage defaults. Sweden is indeed very different from the United States in these respects. ${ }^{20}$

Could household debt and housing prices cause problems for the macroeconomy? Several considerations suggest that the danger is small. First, model simulations of a housing price fall show that expansionary monetary policy can neutralize the negative effects on aggregate demand and inflation from a housing price fall, even taking into account the ZLB. Second, the assets of Swedish households (excluding pension claims) are, in the aggregate, three times their debt, so that household equity is twothirds of household assets, resulting in a quite low leverage. Nor is there any trend toward higher leverage. Third, the household saving ratio is high, so there is no evidence of aggregate consumption being financed by withdrawal of housing equity. ${ }^{21}$ Fourth, an ambitious Riksbank research project on the housing market (Sveriges Riksbank 2011d) has confirmed that housing prices are consistent with fundamentals and that there is no evidence of a bubble or overvaluation. If housing prices are consistent with fundamentals, then the fundamentals themselves would have to fall for housing prices to decline. This is a much more benign situation than a bubble that might burst.

Finally, a debt-to-disposable income ratio as high as 170 percent is fully sustainable, and a constant ratio at this level requires only a very small "primary surplus" as a share of disposable income, when not only nominal interest payments but the households' complete net cash flow, that is, net debt service considering after-tax interest payments and net amortization, is taken into account. (With a high 7 percent nominal mortgage rate, a 30 percent deductible capital income tax, and 4 percent nominal disposable income growth only a steady-state after-tax primary surplus of about 1 percent $[=7(1-0.3)-4$ percent] of the debt-to-disposable income ratio is required; see appendix A3 in the online appendix for details.)

On the second question, even if household debt and housing prices were considered a problem, considerable research indicates that the policy rate has a limited impact on either (the two are highly correlated, since most household debt is in the form of mortgages), but that a rise in the policy rate can cause sizable collateral damage in the form of negative effects on inflation and real activity. ${ }^{22}$ A number of 
more efficient instruments are available to influence household debt and housing prices, such as loan-tovalue ceilings, amortization floors, property taxes, and limitations on tax deductions.

In general, if there is some probability of a future housing price fall, and such a fall is expected to have an impact on future aggregate demand, resource utilization, and inflation, then that impact should be taken into account in constructing the mean forecasts of inflation and resource utilization. Then one could derive the correct implications for the policy rate and best stabilize inflation and resource utilization. The impact could imply a downward shift of future resource utilization and inflation, which in itself would seem to imply more expansionary rather than contractionary policy. Furthermore, if the policy rate is deemed to have some effect on the probability or the magnitude, or both, of a housing price fall, this should also be taken into account. It could imply more contractionary policy, if a higher policy rate was deemed to reduce the probability or the magnitude of such a fall. But in the absence of such an analysis it is not clear what the policy implications are.

Donald Kohn $(2006,2008)$ mentions three conditions that should be fulfilled before central banks implement "extraordinary actions" to handle possible asset price bubbles, such as an unsustainable increase in housing prices: "First, policymakers must be able to identify bubbles in a timely fashion with reasonable confidence. Second, a somewhat tighter monetary policy must have a high probability that it will help to check at least some of the speculative activity. And third, the expected improvement in future economic performance that would result from the curtailment of the bubble must be sufficiently great." These conditions will rarely be fulfilled in practice.

Occasionally, the minutes of the Riksbank meetings refer to the impact of the policy rate through household debt and housing prices on outcomes well beyond the forecast horizon of 3 years. However, the connection between these outcomes and the current policy rate is often difficult to articulate. Normally there is little or no information about the impact of the policy rate on the outcome beyond the forecast horizon. Responding to information that we do not really have only introduces random errors in policy. ${ }^{23}$

\section{IV.D. The Normalization Argument}

Another argument is that, all else equal, low interest rates will lead to unspecified financial imbalances and unspecified threats to financial stability. This argument seems related to worries about increased leverage and increased risk taking - consistent with the so-called risk taking channel - and the misallocation of investment. Such arguments imply that, for given forecasts of inflation and resource utilization, more normal interest rate levels are preferred. It is similar to adding a term $\left(i_{t}-i^{*}\right)^{2}$ to the loss function, where $i_{t}$ denotes the policy rate in period $t$ and $i^{*}$ denotes the normal policy rate. This term would represent undesirable impacts of lower than normal policy rates that are not included in the forecasts of inflation and resource utilization. There are several references to "normalization" in Riksbank press releases, Monetary Policy Reports and Updates, minutes, and speeches.

However, there is no evidence that low interest rates lead to more leverage or more risk taking in Sweden. The Swedish financial sector is dominated by an oligopoly of four large commercial banks, and there is no shadow banking sector to speak of. There is no evidence that these commercial banks tend to increase their leverage when the policy rate is low. ${ }^{24}$ Furthermore, even if lower policy rates did lead to more risk taking, it does not follow that the resulting amount of risk taking would be too much. That depends on what the optimal level of risk taking is. In the wake of the financial crisis, it might be that risk 
aversion and the perception of uncertainty are exceptionally high and that there is overall too little risk taking. Without further analysis, this cannot be known. ${ }^{25}$

The argument that low interest rates would lead to misallocation of investment is much weakened by the fact that the level of investment in Sweden has been very low and is still lower today than before the crisis. There has been little construction - certainly no construction boom - and no overinvestment in housing. The argument would further require a downward bias in the estimate of capital costs during the lifetime of the investments that are undertaken. I am not aware of any evidence of such bias.

Furthermore, the general discussion about policy rates, the risk taking channel, and so on, and the existing models, consistently seem to suffer from confusion between nominal policy rates and the general level of real interest rates. Models such as those of Tobias Adrian and Hyun Song Shin (2011) and Douglas Diamond and Raghuram Rajan (2011) include a short real rate but no nominal policy rate and no explicit monetary policy. ${ }^{26}$ Nor do they distinguish between the short real rate and the neutral real rate (also called the natural real rate). All that monetary policy can do by setting a short nominal policy rate is to temporarily make the short real rate deviate from the neutral real rate, which itself is beyond the control of monetary policy. The effects attributed to monetary policy should be the effects of that difference, not the level of the neutral rate or the overall level of the real rate. The neutral real rate is affected by many things and can remain low for many years for several reasons, including global imbalances, fiscal policy, and shocks to aggregate demand and supply. (Online appendix A5 provides an illustration with the simplest New Keynesian model.)

\section{Arguments against the FOMC's Policy Easing}

The argument for more expansionary U.S. monetary policy, if possible, in June 2010 is also straightforward: the FOMC's projections for underlying inflation were below the mandate-consistent level, and its projections for unemployment were above the estimate of the sustainable rate. Indeed, noting these facts, Chairman Bernanke (2010b) concluded at the time, "Given the Committee's objectives, there would appear - all else equal - to be a case for further action." However, some arguments against more expansionary policy have been put forward. From my reading of the FOMC minutes and the broader debate about U.S. monetary policy, I find that the various arguments can be organized as follows: ${ }^{27}$

- concerns about increased inflation and the anchoring of inflation expectations

- uncertainty about the effects of unconventional policy measures on the economy

- concerns about the possible negative effects of low policy rates for an extended period on financial stability and the allocation of investment

- concerns about estimates of the amount of slack in the economy

- concerns on the part of emerging-market policymakers that the policy would result in increased capital inflows into those countries, possibly generating bubbles and other negative impacts there - concerns that the Federal Reserve's balance sheet would be more exposed to possible capital losses.

\section{V.A. Concerns about Increased Inflation and the Anchoring of Inflation Expectations}

One argument is that an expansion of the Federal Reserve's balance sheet risks reducing public confidence in the Federal Reserve's commitment to price stability. Some observers might erroneously think that a large increase in the balance sheet, since it implies a larger monetary base, will automatically bring higher inflation, especially since future circumstances may make it difficult to scale back the 
balance sheet quickly. This may increase longer-run inflation expectations, possibly with a ratchet effect, and ultimately require a recession to reduce them.

Why do inflation expectations matter for monetary policy? First, because all else equal, higher inflation expectations raise actual inflation and the inflation forecast. If expectations instead are anchored on the central bank's inflation objective, it is easier for the central bank to stabilize both inflation and resource utilization. Second, they matter because the proximity of long-run inflation expectations to the inflation objective provides a good indicator of the central bank's credibility or, more precisely, of belief in its ability to attain the objective. This indicator is of some independent interest, for instance for policy evaluation. But, importantly, the mandate of the Federal Reserve (and of the Riksbank) includes price stability, not stability of inflation expectations. Inflation expectations should therefore not be taken as an independent target variable. At most, they are an intermediate target variable, whose stability simplifies the stabilization of the actual target variables.

As an illustration, consider the standard New Keynesian Phillips curve,

$$
\pi_{t}-\pi^{*}=\delta\left(\pi_{t+1 \mid t}-\pi^{*}\right)+\kappa x_{t}+\varepsilon_{t}
$$

where $\pi_{t}$ denotes inflation in period $t, \pi *$ is the inflation objective, $\delta$ is the private sector discount factor, $\pi_{t+1 \mid t}$ denotes private sector expectations in period $t$ of inflation in period $t+1, x_{t}$ denotes the output gap, $\varepsilon_{t}$ denotes a possibly serially correlated cost-push shock, and $\kappa$ is a positive constant. ${ }^{28}$ Shocks to private sector inflation expectations will, all else equal, imply shocks to inflation. Stable inflation expectations make it easier to stabilize inflation around $\pi^{*}$ and the output gap around zero. Higher inflation expectations will, all else equal, imply higher actual inflation. Inflation expectations above $\pi^{*}$ will, all else equal (zero cost-push shocks), require a negative output gap to keep inflation at $\pi^{*}$.

A good inflation forecast implicitly incorporates a forecast for inflation expectations. Note, however, that there is a risk of double counting: If inflation expectations are forecast to increase, and inflation forecast takes this into account, the increase in inflation expectations contains no additional information that is not already contained in the inflation forecast. Responding to inflation expectations beyond the response to the inflation forecast could then be excessive.

Let $\pi_{t+\tau, t}$ denote the central bank's mean forecast in period $t$ of inflation in period $t+\tau$. It is, by equation 1, given by

$$
\pi_{t+\tau, t}=\pi^{*}+\delta\left(\pi_{t+\tau+1 \mid t+\tau, t}-\pi^{*}\right)+\kappa x_{t+\tau, t}+\varepsilon_{t+\tau, t}
$$

and hence depends on the central bank's forecast in period $t$ of private sector inflation expectations in period $t+\tau, \pi_{t+\tau+1 \mid t+\tau, t}$, and on forecasts in period $t$ of the output gap and the cost-push shock in period $t+$ $\tau, X_{t+\tau, t}$ and $\varepsilon_{t+\tau, t}$. The effect of private sector inflation expectations is fully incorporated in the inflation forecast. $^{29}$

Arguably, an increase in shorter-run inflation expectations above the inflation objective would not actually be a problem in the current situation of a binding ZLB. On the contrary, a temporary increase would reduce the real interest rate and stimulate the economy and would therefore be desirable. 
Furthermore, according to Qvigstad's (2005) criterion, if the unemployment forecast is above the sustainable unemployment rate, optimality requires that the inflation forecast be above the inflation objective.

What would be a problem is if longer-run inflation expectations were to increase and require tight policy for a significant period to be brought down. Clear communication about the purpose of the expansion should mitigate the risk of a reduction in public confidence in the central bank's long-run commitment to price stability.

Regarding the increase in the monetary base that follows from the Federal Reserve's asset purchases, the fact that the Federal Reserve can pay interest on reserves means that a large monetary base no longer by itself leads to inflation. In the standard textbook treatment, a large monetary base implies a zero policy rate. But the Federal Reserve's ability to pay interest on reserves implies that a large monetary base does not prevent it from setting the policy rate at any level required to restrict aggregate demand and thereby limit inflation. Clear communication of this fact should reduce naïve beliefs of the opposite. Yet these beliefs seem quite stubborn, in spite of rather clear communication by the Federal Reserve. In any case, short- and long-run inflation expectations are monitored very closely in real time, and the Federal Reserve has the option of modifying its policy if inflation expectations start to move in undesirable directions.

Moreover, there seems little danger in the United States today of a ratchet effect in inflation expectations. The Federal Reserve's mandate of price stability is well established. Long-run inflation expectations are well anchored in the United States, as in the euro area and in other advanced countries with inflation targeting. As argued by Adam Posen (2011), nervousness about inflation expectations being sticky downward may stem from the stagflation experience in the 1970s. The struggle of some countries with bad inflation histories to achieve credibility for newly established targets in the early 1990s may also be a factor. But the success of inflation targeting in an increasing number of advanced and emergingmarket countries in bringing low and stable inflation should dampen this nervousness.

Finally, as discussed by Evans (2011), the Federal Reserve's objective to stabilize inflation around the mandate-consistent rate should be interpreted as a symmetric objective, and the mandate-consistent rate should not be interpreted as a cap on inflation. Therefore, when unemployment is too high, inflation above the mandate-consistent rate is not in itself a problem. According to the Qvigstad criterion, it is instead a condition for optimal policy.

\section{V.B. Uncertainty about the Effects of Unconventional Policy Measures}

It has been argued that additional expansionary policy measures when the ZLB is binding may have limited effects on the economy, and because of this, that attempts by the Federal Reserve to use such measures might reduce its credibility and perceived competence, making it less effective at stabilizing inflation and resource utilization in the future.

There is a lively debate and now a considerable body of research on the effects of large-scale asset purchase programs (LSAPs). ${ }^{30}$ Estimates based on a number of recent studies, as well as the Federal Reserve's own estimates, suggest that, all else equal, QE2 lowered longer-term interest rates by 10 to 30 bp. Federal Reserve analysis further indicates that such a reduction is roughly equivalent in its economic effect to reducing the federal funds rate by 40 to 120 bp (Bernanke 2011a) - a large reduction. In 
simulations using the FRB/US macroeconomic model, discussed by Janet Yellen (2011b) and reported by Hess Chung and others (2011), QE2 is assumed to lower 10-year yields by about $15 \mathrm{bp}$, which would reduce the unemployment rate by about 0.3 percentage point and increase core PCE inflation by about 0.2 percentage point. ${ }^{31}$ This is to my mind a substantial effect.

According to the so-called portfolio balance channel, LSAPs affect long-term interest rates by changing the quantity and mix of financial assets held by the public. This assumes that different financial assets are not perfect substitutes in investors' portfolios, so that changes in the net supply of an asset affect its yield and those of broadly similar assets.

LSAPs can be seen as a shortening of the duration of the public debt; they result in privately held public debt consisting of relatively fewer long-term Treasury bonds and relatively more deposits in the Federal Reserve. They also simply reduce the amount of Treasury securities available to the public, replacing them with deposits at the Federal Reserve. However, a change in the balance of new Treasury issues of short- and long-term debt can to some extent undo this shortening of duration (Hamilton and $\mathrm{Wu}$ 2011). Thus, cooperation by the Treasury, including a commitment not to undo the LSAPs, may be desirable and may increase their effect.

The Federal Reserve's purchases of Treasury securities, by removing substantial quantities of these securities from the market, should induce private investors to buy other assets that serve as substitutes for Treasuries, such as corporate bonds and mortgage-backed securities. The result is to reduce the yields and increase the prices of those other assets as well, lowering borrowing costs and easing financial conditions throughout the economy (Bernanke 2011a).

As discussed in section I, an increase in uncertainty that does not change the means (a meanpreserving spread) should normally not change the optimal policy. The direction of the optimal policy adjustment in response to increased and more complex uncertainty, such as model and multiplicative uncertainty, is usually not clear from the available information. Hence an increase in uncertainty by itself provides no reason to deviate from the normal response to the mean forecasts, that is, from the certaintyequivalent policy.

About a decade ago, many academics, including myself, criticized the Bank of Japan for not doing more when it faced the ZLB. The reason for its inaction seemed to be that the effectiveness of further policy measures was uncertain, and it was therefore safer not to try. As I wrote at the time (Svensson 2001), "The logic of this argument escapes me. Instead...it seems that, if a monetary expansion is deemed desirable, prudent policy calls for trying a number of the suggested remedies (as long as they are not inconsistent), in the hope that some may work." I remain convinced that uncertainty about the effects of unconventional policy is not a valid reason to do nothing. The Federal Reserve has indeed acted very forcefully in undertaking LSAPs, even though the magnitude of the effect on the economy was very uncertain ex ante.

\section{V.C. Concerns about the Effects of Low Policy Rates on Financial Stability and Investment Allocation \\ Although I feel confident in rejecting this argument for Sweden (see section IV.D), I am less informed about the U.S. situation, with its substantial shadow banking sector and complicated supervisory and regulatory framework, with responsibilities divided among several authorities. Yellen (2011a) describes how the Federal Reserve is engaged in monitoring a number of indicators of potential financial}


market imbalances. These include indicators of asset valuations relative to historical norms such as forward price-to-earnings ratios in the stock market and price-to-rent ratios in the real estate market, as well as various measures of risk premiums and debt growth. The Federal Reserve has also intensified its monitoring of leverage, particularly outside the traditional banking system. This includes gathering both supervisory and market surveillance data and initiating an ongoing dialogue with a range of market participants to obtain more detail on the complex use of leverage in the shadow banking sector. At present, the Federal Reserve sees few indications of significant imbalances, and the use of leverage seems well below precrisis levels.

As noted in section IV.D, much theoretical and empirical work on the possible consequences of low interest rates on leverage and risk taking confuses the policy rate, the real rate, and the natural real rate and does not appreciate that the relevant impact of monetary policy is the impact of temporary deviations of the short real rate from the natural real rate. This means that the conclusions of this work for monetary policy are not clear.

The situation in the United States regarding the housing market and housing construction is hardly an argument against more expansionary policy. Continued housing price declines and a construction slump are rather arguments for more expansionary policy. As for any misallocation of investment, again, this requires a systematic bias in the estimates of capital costs during the lifetime of the investment.

In a second-best situation, without appropriate supervision and regulation, if the policy rate is the only available tool and there is a trade-off between its effect on the monetary policy objectives and financial stability, that trade-off should be taken into account. Normally, however, the policy rate is not the only available tool, and much better instruments are available for affecting financial stability. Given this, one can aruge that monetary policy and the policy rate should be the last line of defense, when other policy measures have been exhausted. Kohn's three conditions, discussed above, also apply here.

\section{V.D. Concerns about Estimates of Economic Slack}

It has been argued that there may be less slack in the U.S. economy than commonly appreciated, because the structural unemployment rate, the NAIRU, and the short-term equilibrium unemployment rate may have increased. For instance, the observed increase in longer-term unemployment may lead to an erosion of skills and the need to reallocate labor across sectors that require new skills, and may make the matching of the unemployed to vacant jobs more difficult. However, even if an increase in short-term equilibrium unemployment rates has occurred, it seems obvious that it is dwarfed by the large rise in unemployment during the crisis.

Furthermore, as discussed in section I and in Bernanke (2010b), there are good reasons why the mandate-consistent unemployment rate should be interpreted the sustainable unemployment rate, that is, the long-run equilibrium unemployment rate. Then, the relevant target variable, besides inflation, is the gap between unemployment and the sustainable rate, not that between unemployment and any short-run equilibrium unemployment concept. The latter is relevant for the impact on inflation and the inflation forecast, but not as a target variable. Using it as the target variable in effect introduces a preference for constant inflation, which I find difficult to motivate. (See online appendix A1 for more details.)

In particular, in a situation with high unemployment, increased longer-term unemployment, skills erosion, increased needs to reallocate labor, less effective matching, and thereby a higher short-run 
equilibrium rate (if this can be defined), expansionary policy may quickly drive unemployment down toward the sustainable unemployment rate, speed up the reallocation, limit the erosion of skills or speed the acquisition of new ones, and bring down not only actual unemployment but also the short-run equilibrium unemployment rate. The cost of this may be higher inflation, but this cost is appropriately taken into account by the squared gap between actual inflation and the mandate-consistent rate. The benefit is measured by the reduction in the squared gap between unemployment and the sustainable unemployment rate times the weight on that term.

\section{V.E. Concerns about Increased Capital Inflows into Emerging Markets}

Some policymakers in emerging-market economies have expressed concerns about increased capital flows into their countries and the related risks of bubbles and other negative effects there. However, the Federal Reserve's mandate concerns only U.S. inflation and employment; it is not responsible for inflation, real developments, or monetary policy in other countries except as they feed back into the United States. That responsibility should rest with the policy authorities in those countries. Countries with a peg to the dollar will tend to import expansionary U.S. monetary policy, possibly causing the economy to overheat. A flexible exchange rate gives countries the option to run an independent monetary policy appropriate for the country. If countries nevertheless choose a dollar peg, and this results in capital inflows, bubbles, and other negative effects, they are themselves responsible for those effects.

In principle, more expansionary U.S. monetary policy, for instance in the form of lower long-term interest rates, tends to depreciate the dollar, all else equal. Does this mean that the United States is conducting a beggar-thy-neighbor policy? I do not see it that way. A weaker currency is a normal consequence of more expansionary policy in an open economy. Each of the countries affected has the option of adjusting its own monetary policy in response. All countries cannot depreciate their currency against each other, but all countries can conduct more expansionary policy if they prefer, whether through conventional or unconventional methods. Such a policy will increase real activity, world trade, and imports, which in a situation of underutilized resources is to the benefit of all. Monetary policy is not a zero-sum game.

\section{V.F. Concerns about Federal Reserve Balance Sheet Losses}

The Federal Reserve could indeed realize a loss when it sells its holdings of long-term Treasury bonds. However, any such capital loss for the Federal Reserve would be a (possibly unrealized) capital gain for the Treasury, so the consolidated government sector would not be affected. If capital losses by the Federal Reserve are considered a problem, a possible solution is for it to be compensated by the Treasury. Also, since the Federal Reserve can raise the interest rate on reserves, it need not sell assets to tighten policy but can keep them to maturity. Furthermore, central banks are different from commercial banks in that they can operate with negative capital, as long as the income from their assets exceeds operating costs (including interest on reserves) by a sufficient margin, so that cash flow is positive. For the Federal Reserve to have a negative cash flow would require very high interest rates on reserves. Even then, the Federal Reserve could actually sell assets to finance the negative cash flow for a long time (see Reis 2009 and Rudebusch 2011 for details). Nevertheless, these facts do not preclude that capital losses for the Federal Reserve might cause political or communication problems.

\section{The Situation One Year Later}


Figure 6 shows realized PCE and core PCE inflation and the FOMC's forecast, and realized CPIF inflation and the Riksbank's forecast, in the summer of 2011. The forecast for PCE inflation was by then above the mandate-consistent rate for 2011 and early 2012 but below that rate for the rest of 2012 and 2013. The forecast for core PCE inflation was below the mandate-consistent rate throughout the forecast period but consistent with the higher PCE inflation rate for 2011 because of temporary factors. ${ }^{32}$ The Riksbank's CPIF forecast was above the target for 2013 but below the target on average over the forecast period.

Figure 7 shows the corresponding unemployment forecasts. The FOMC's estimated sustainable unemployment rate was by then 5.4 percent, ${ }^{33}$ higher than the June 2010 estimate of 5.1 percent. The Riksbank was still using 6.5 percent as the sustainable unemployment rate. Sweden's National Institute for Economic Research (2010) published an estimate of about 6.5 percent in June 2010, but in March 2011 it revised this down to just above 6 percent (NIER 2011a). ${ }^{34}$ In May it published a report estimating the sustainable unemployment rate at either 5 or 6 percent, depending on assumptions about the wage formation process (NIER 2011b). In April 2011 the Ministry of Finance (2011) published an extensive analysis of the effects of Sweden's substantial structural reforms, tax changes, and other factors, including demography and labor force composition, that have an impact on the sustainable unemployment rate. It arrived at an estimate of 5 percent. I consider this study the best analysis so far. My own preliminary estimate of 5.5 percent (Sveriges Riksbank 2010c) is approximately the midpoint between that of the Ministry of Finance and that of the National Institute of Economic Research and is marked in figure 7. The full range of estimates above is also indicated in the figure.

Figure 6. Inflation, Realized and June/July 2011 Central Bank Forecasts, Sweden and United States Percent per year

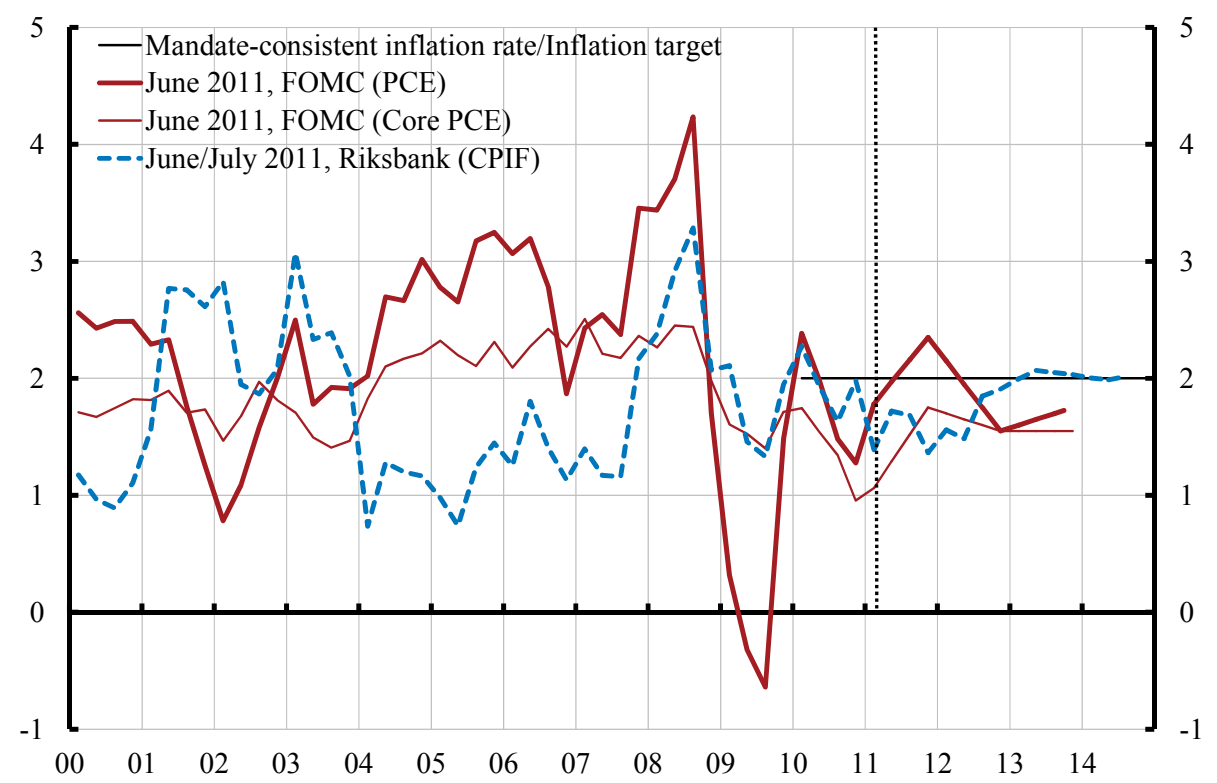

Sources: The Bureau of Economic Analysis, the FOMC, Sveriges Riksbank, and Statistics Sweden. Note: The vertical line indicates 2011Q1, the last quarter for which inflation outcomes were available for the FOMC's and the Riksbank Executive Board's June/July 2011 meetings. The extensions to the right of the vertical line are the forecasts announced after those meetings. The horizontal line indicates the median of FOMC participants' longer-run projections of PCE inflation as of the June 2011 meeting, rounded from 1.95 percent. The Riksbank's inflation target is also 2 percent. 
The FOMC's June 2011 unemployment forecast was above the sustainable rate. The Riksbank's forecast was on average above the range of estimates of the sustainable rate, and clearly above the estimates of the NIER and the Ministry of Finance and my own estimate.

In this situation the FOMC (2011b) kept its policy rate unchanged, announcing that

The Committee continues to anticipate that economic conditions - including low rates of resource utilization and a subdued outlook for inflation over the medium run - are likely to warrant exceptionally low levels for the federal funds rate for an extended period. The Committee will complete its purchases of $\$ 600$ billion of longer-term Treasury securities by the end of this month and will maintain its existing policy of reinvesting principal payments from its securities holdings. ${ }^{35}$

For its part, the Riksbank continued to raise the policy rate, this time from 1.75 percent to 2.0 percent, and announced (Sveriges Riksbank 2011b) that its forecast for the repo rate was unchanged. Deputy Governor Ekholm and I again dissented. ${ }^{36}$

Figure 7. Unemployment Rate, Realized and June/July 2011 Central Bank Forecasts, Sweden and United States

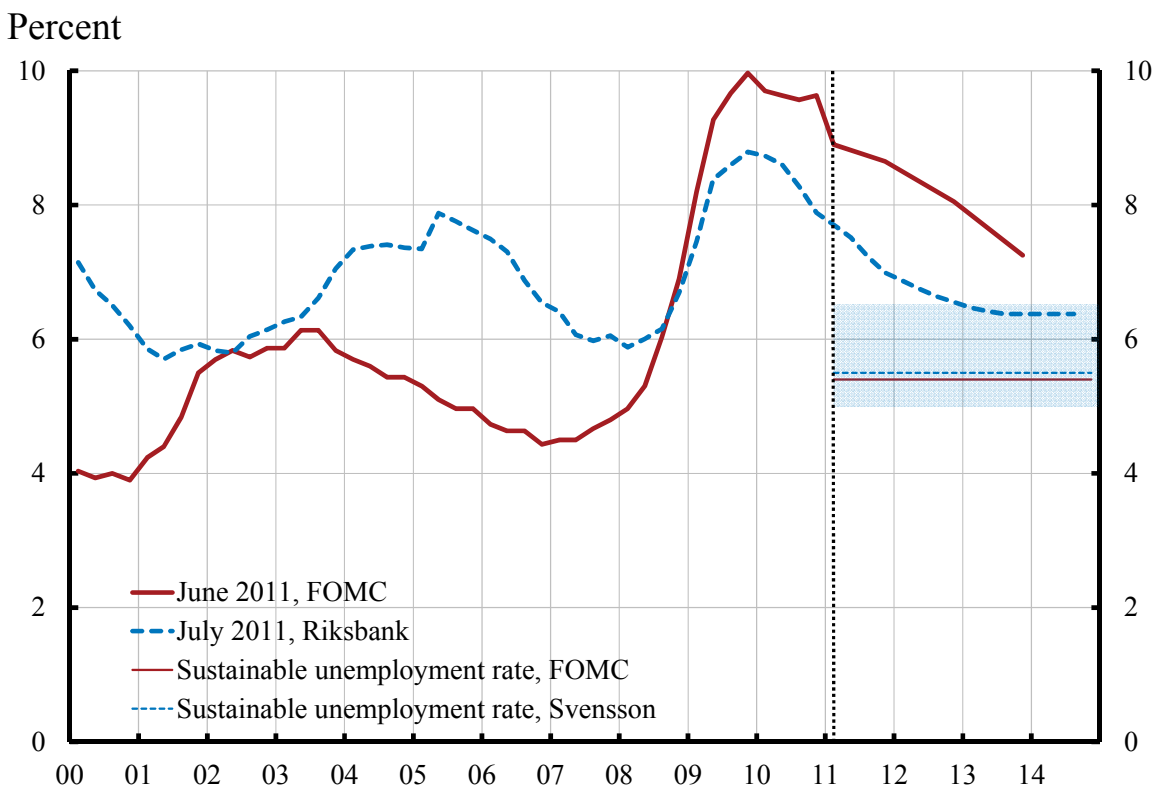

Sources: Bureau of Labor Statistics, FOMC, Sveriges Riksbank, and Statistics Sweden.

Note: The vertical line indicates 2011Q1, the last quarter for which unemployment rate outcomes were available for the FOMC's and the Riksbank Executive Board's June/July 2011 meetings. Forecasts are those of the respective central banks announced after those meetings. The extensions to the right of the vertical line are the forecasts announced after those meetings. The series of Swedish realized unemployment rates differ from the one in figure 2 because of some data revisions, mainly before mid2005. The horizontal red solid line shows the median of FOMC participants' projections of the longer-run unemployment rate, as of the June 2011 meeting. The horizontal blue dotted line shows my estimate of the sustainable unemployment rate for Sweden. The blue shaded area shows the range of sustainable rate estimates for Sweden. 
Figure 8 shows the federal funds rate and market expectations of future federal funds rates after the Federal Reserve's announcement. The market expected the federal funds rate to be exceptionally low for more than another year. The figure also shows the Riksbank's repo rate, the forward rate curve, and the announced policy rate path. The market still expected a noticeably lower path, more than $100 \mathrm{bp}$ lower at the end of the forecasting period.

\section{VI.A. Why Was the Riksbank Policy Rate So High?}

The upward-sloping policy rate path in figure 8 reflects the Riksbank's intended policy in June/July 2011. The policy rate path is indeed very high compared with market implied forward rates and even higher compared with foreign implied forward rates, shown in the top panel of figure 9 (these rates are calculated using Total Competitiveness Weights, which are essentially Swedish trading-partner weights). ${ }^{37}$ One reason for the high Riksbank policy rate is that the Riksbank's forecast of foreign policy rates, also shown, was much higher than the foreign implied forward rates. The bottom panel of figure 9 shows that this divergence persisted in July 2011.

Figure 8. Policy Rates, Policy Rate Expectations, and Riksbank Policy Rate Path, June/July 2011, Sweden and United States

Percent per year

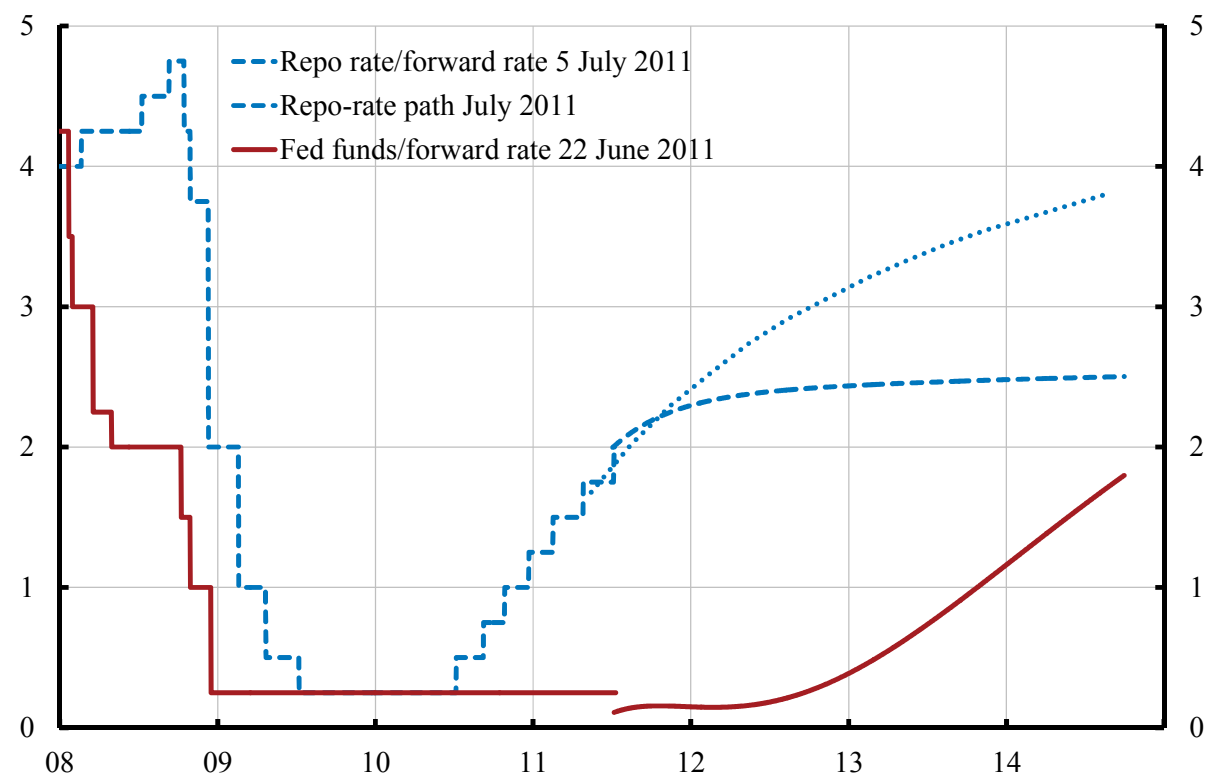

Sources: Reuters EcoWin and Sveriges Riksbank.

Note: Forward rates are adjusted for normal forward term premiums (assumed to be $1 \mathrm{bp}$ per month).

Indeed, Riksbank forecasts of foreign policy rates have been much above the implied forward rates since 2009. The forward rates have not been very good forecasts, but they have been much better than the Riksbank's (see figure A2 in the online appendix). The Riksbank's forecast for foreign policy rates has arguably been systematically too high for several years. A too-high forecast for foreign policy rates biases the repo rate path upward, all else equal. A higher policy rate path for foreign rates, all else equal, leads to a weaker forecast for the Swedish krona, and the Swedish repo rate path must then be higher to counteract this. Deputy Governor Ekholm and I consider it more appropriate to adopt a forecast 
for foreign policy rates that starts from implied forward rates and is then adjusted for any further information about foreign monetary policy intentions.

A second source of upward bias in the policy rate path is a possible overestimation of the sustainable unemployment rate (see above) and underestimation of potential output. The Riksbank's measures of potential output have shifted down substantially relative to precrisis levels (figure 4), implying a less negative output gap and a bias toward higher resource utilization. Potential outputs for September 2008 and June/July 2010 were constructed with a Hodrick-Prescott (HP) filter, which has a well-known endpoint problem, which implies that the output gap always tends to be closed at the end of the forecast horizon (see, for instance, Apel, Hansen, and Lindberg 1996). Potential output for July 2011 is constructed using a new production function approach, but it retains the properties of an HP filter, and potential productivity is still estimated with an HP filter.

Figure 9. Riksbank Policy Rate Path and Foreign Policy Rate Forecast, and Market Forward Rates, 2010 and 2011

June/July 2010

Percent

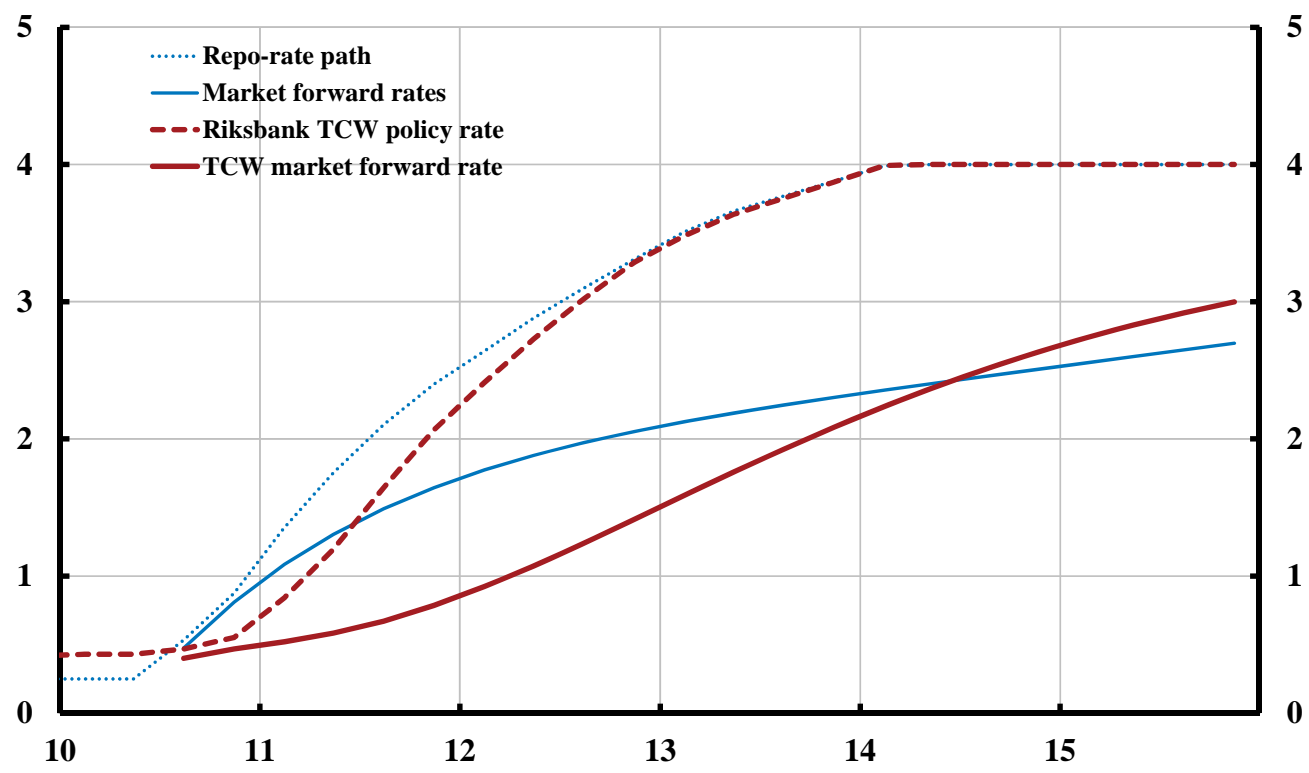

July 2011

Percent 


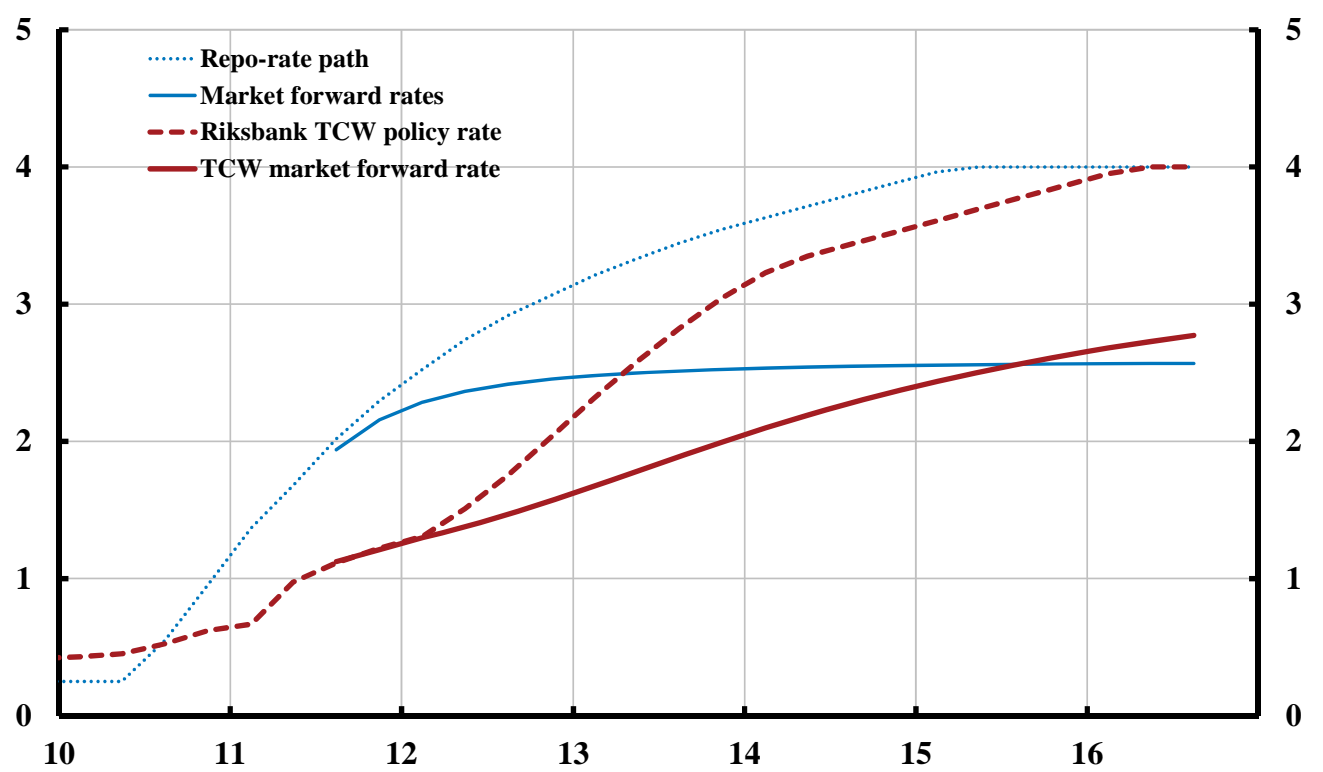

Sources: Reuters EcoWin, Sveriges Riksbank, and author's calculations.

Note: Calculated using Total Competitiveness Weights.

As discussed previously, if the shock to the Swedish economy was mainly a shock to aggregate demand through a fall in exports, it is not clear why potential output would be much affected. Nor is it clear why past potential output would have to be adjusted so much that 2007Q4 comes to be considered a boom as high as the recession in 2009Q9 was deep, particularly given that in September 2008, the boom in the previous year was considered quite moderate. ${ }^{38}$

Figure 10 shows estimates and forecasts of U.S. potential output by the Congressional Budget Office (CBO) in September 2008, August 2010, and August 2011, together with FOMC forecasts of GDP in June 2008, 2010, and 2011. The figure shows that the CBO does not adjust past estimates of potential output as much as the Riksbank, nor do its estimates and forecasts look like HP-filtered series. For these reasons, as discussed in Svensson (2011a), I have become skeptical about Riksbank estimates of potential output and regard the gap between unemployment and the sustainable unemployment rate as a more relevant, reliable, and transparent indicator of resource utilization as a target variable.

Figure 10. GDP, Realized and Forecast, and Potential GDP, United States

Index, 2007Q4 realized GDP $=100$ 


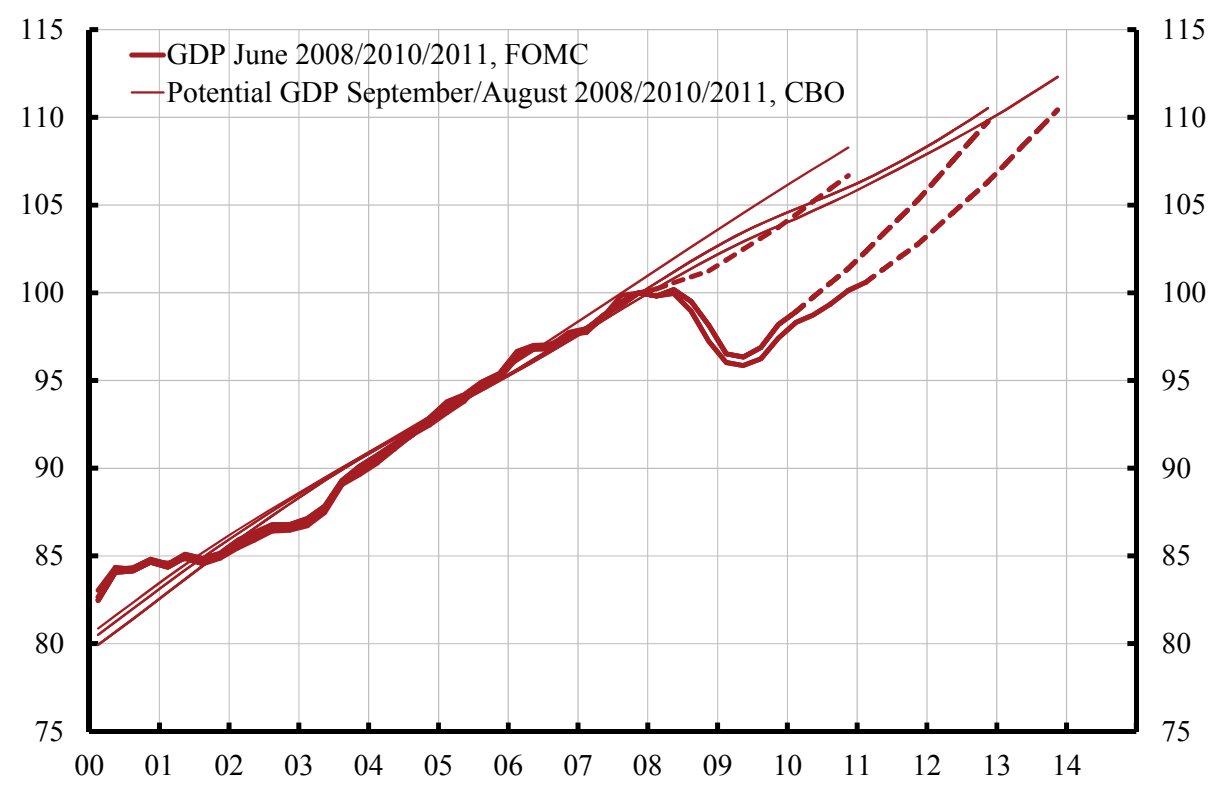

Sources: Congressional Budget Office and FOMC.

Notes: For each date, the thick solid line represents the most recently available estimates of realized GDP, the dashed line the FOMC's GDP forecast (as of June 2008, June 2010, and June 2011), and the thin solid line the CBO's then-current estimate and forecast of potential GDP (as of September 2008, August 2010, and August 2011).

Online appendix A6 shows Riksbank policy alternatives in July 2011 under the assumption of forecasts of foreign policy rates in line with market forward rates and a sustainable unemployment rate of 5.5 percent. These alternatives are also discussed in the minutes of the July 2011 meeting (Sveriges Riksbank 2011a).

\section{VI.B. Why Did the Swedish Economy Perform Better in 2010 than Forecast?}

As reported above, at its June/July 2010 meeting the Riksbank began to raise the repo rate, even though inflation by the CPIF forecast was undershooting the target and the forecasts for all measures of resource utilization were below sustainable levels. The Riksbank thus was tightening despite monetary policy not being well balanced to begin with, and despite Qvigstad's (2005) criterion for a well-balanced monetary policy not being met. Under these conditions one might have expected that the real economy would perform rather poorly. Instead, GDP growth in 2010 was more rapid than expected (figures 4 and 5). Although GDP in July 2011 was just above the precrisis level, it had increased much more than was forecast in June/July 2010. Unemployment, although still high, had also come down more than forecast (compare figures 2 and 7).

Does this better-than-expected performance mean that the policy tightening that began in June/July 2010 was appropriate ex post? Recall that when evaluating past policy, one must distinguish between evaluation ex ante and ex post, and that evaluation ex post to a considerable extent means assessing whether policymakers were lucky or unlucky.

Had the Riksbank known in June/July 2010 that the Swedish economy would perform as well as it did, would it have been consistent with its mandate to start tightening? My answer is no. A year later, 
inflation and the inflation forecast, although higher, were still too low, and unemployment and the unemployment forecast, although lower, were still too high. More expansionary policy in June/July 2010 would have had better results, with inflation higher and unemployment lower.

But why did the Swedish economy perform better than anticipated in the summer of 2010 ? Sveriges Riksbank (2011c) mentions higher-than-expected exports, domestic demand, and productivity. A possible explanation, not mentioned in that report, is that actual financial conditions (that is, the actual market term structure of interest rates) were substantially more expansionary than the intended financial conditions (the market term structure consistent with a credible policy rate path and normal forward term premiums). From the beginning of 2010 until July 2011, Swedish 5-year interest rates were on average about 85 bp lower than the average consistent with a credible policy rate path and normal forward term premiums. Thus, the Swedish economy may have benefited from the market effectively implementing a more expansionary policy than that intended by the Riksbank. But since forecast inflation was still too low and forecast unemployment too high, even more expansionary policy would have been better.

This can be seen from the top panel of figure 11, which shows the actual yield curve and the yield curve compatible with the repo rate path, both as of June/July 2010; the former represents actual financial conditions, and the latter represents intended financial conditions; it is the yield curve that would arise if the repo rate path was fully credible and credit and forward term premiums were normal. ${ }^{39}$ When the two curves differ, it is the former that affects the Swedish economy, not the latter. And according to the figure, they differed substantially: the actual 5-year interest rate at that time was slightly more than 100 bp lower than the 5-year rate compatible with the repo rate path. A regression of the 5-year rate on a 3-month rate indicates that a 100-bp increase in the former is equivalent to an increase in the policy rate of between 200 and $300 \mathrm{bp}$. Such an increase would have been very bad for the economy and would have negatively affected the recovery. The krona would have appreciated substantially, reducing exports. Actual financial conditions were thus much more expansionary than those consistent with the policy rate path. 
Figure 11. Yield Curves, Sweden, 2010 and 2011

June/July 2010

Percent

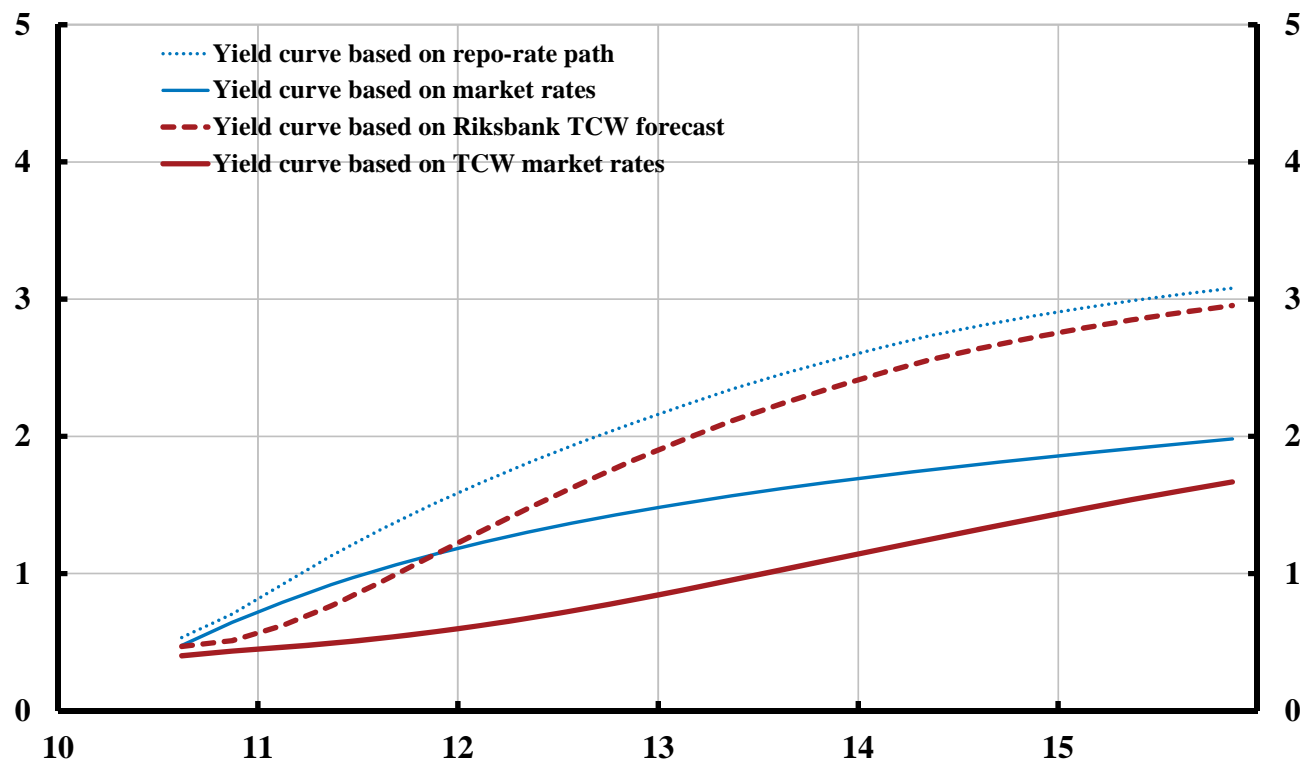

July 2011

Percent

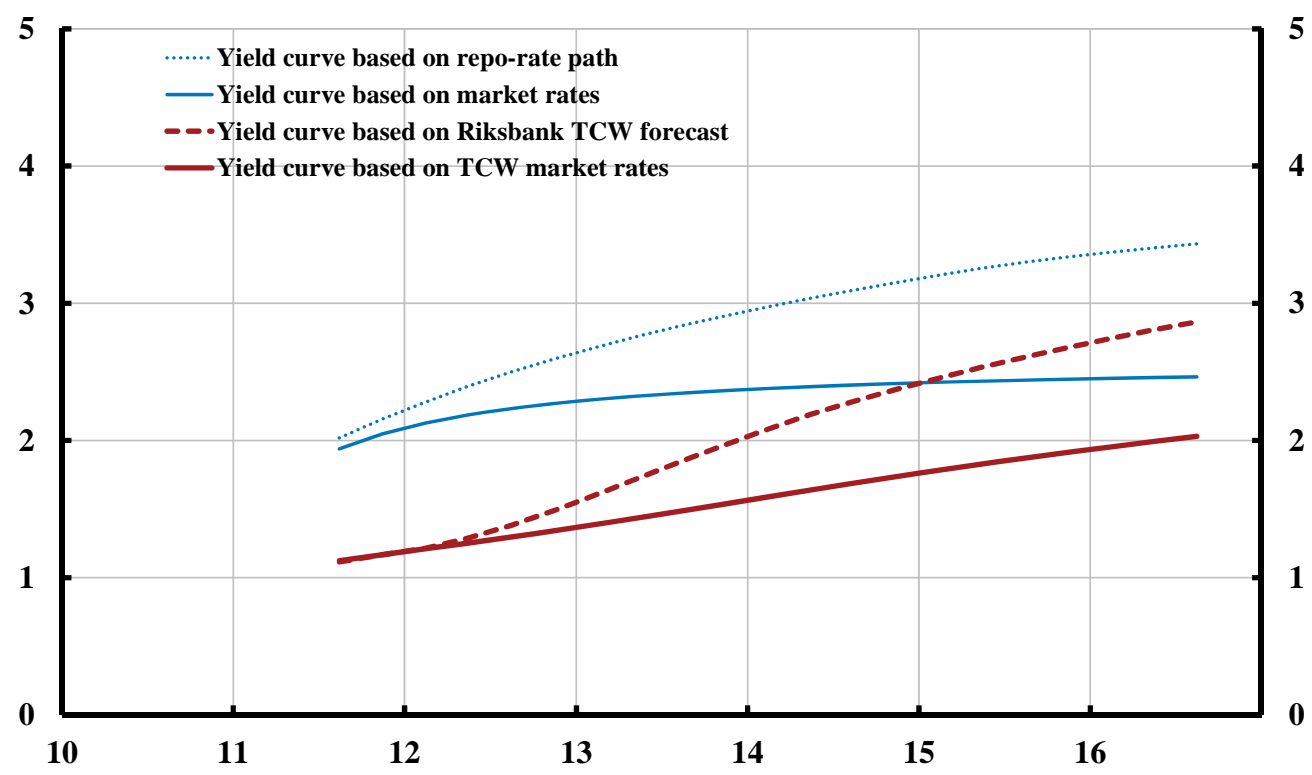

Sources: Reuters Ecowin, Sveriges Riksbank, and own calculations.

In fact, the 5-year rate has been substantially below the level consistent with the policy rate path since February 2010, and the bottom panel of figure 11 shows that in July 2011 the difference between them was still about $100 \mathrm{bp}$. As noted above, since the beginning of 2010, the difference has been on average almost $85 \mathrm{bp}$, equivalent to a reduction in the policy rate path of about 175 to $250 \mathrm{bp}$. Had the 5- 
year rate been on average 85 points higher, the krona would, all else equal, have appreciated substantially, and the recovery would probably have come to a halt.

As mentioned, the effect of lower long-term rates has been discussed at length in the United States, in connection with the discussion of the effects of QE. A common view is that QE in total may have reduced 10 -year rates by around $50 \mathrm{bp}$ or more, primarily by lowering term premiums. According to several analyses (Chung and others 2011, Cúrdia and Ferraro 2011, Fuhrer and Olivei 2011, Yellen 2011b), this may have had significantly positive effects on the U.S. economy and prevented unemployment from being even higher and inflation from being even lower. Using a factor of 4 (as in Bernanke 2011a), a 50-bp-lower 10-year rate is equivalent to a federal funds rate reduction of about 200 $\mathrm{bp}$, comparable to the range of 175 to $250 \mathrm{bp}$ cited above for the repo rate.

\section{Conclusions}

I have started from the observation that in the summer of 2010 the Federal Reserve and Riksbank forecasts for inflation and unemployment were quite similar. The forecasts for inflation were below the Federal Reserve's mandate-consistent rate and the Riksbank's inflation target, and the forecasts for unemployment were above the countries' sustainable rates. Given the mandates of the Federal Reserve and the Riksbank, such a situation would seem to call for more expansionary policy, if possible. But the Federal Reserve and the Riksbank chose dramatically different policies. The Federal Reserve maintained a minimum policy rate, started to communicate possible future easing, and in the fall launched QE2, while the Riksbank started a period of rapid policy tightening. I have examined the arguments against policy easing by the Federal Reserve and the arguments for policy tightening by the Riksbank and have found them unconvincing. Thus, the Federal Reserve appears to have followed its mandate in the summer of 2010, and subsequent adverse economic shocks contributed to weak performance of the U.S. economy. In contrast, the Riksbank appears to have deviated from its mandate, but favorable circumstances contributed to an economic outcome with better performance than might have been expected based on policy choices.

The Riksbank's policy rate path has been very high compared with Swedish market interest rates and foreign market interest rates. As a contributing explanation of the Riksbank's decision, I have pointed to a possible bias in the Riksbank's forecast of foreign policy rates, which is much higher than foreign implied forward rates. This effectively implies an assumption and a forecast of the foreign term structure of interest rates much above the actual one. I have also argued that the Riksbank's estimates and forecasts of potential output in recent years imply a bias toward estimates and forecasts of resource utilization that are too high. The gap between actual unemployment and an estimate of the sustainable unemployment rate is a more reliable and transparent indicator of resource utilization. Ambiguity regarding whether to target stable GDP growth or a stable level of resource utilization may also help explain the choice of a high policy rate path.

A year later, in July 2011, the Swedish economy had performed better than expected, whereas the U.S. economy had performed worse than expected. Sweden's good performance may largely be explained by the market implementing much easier financial conditions than what was consistent with the Riksbank's policy rate path. There were also upward revisions of GDP data. This better-than-expected performance does not mean that the Riksbank's tightening was in line with its mandate ex post; performance would have been better with easier policy and financial conditions. The poorer U.S. performance depends on factors other than monetary policy, including fiscal policy problems (too large a 
subject to address here), a slow recovery of the housing market, and substantial downward revisions of GDP data. Performance would have been even worse without the Federal Reserve's policy easing. Thus, the Federal Reserve appears to have followed its mandate in the summer of 2010, and subsequent adverse economic shocks contributed to weak performance of the U.S. economy. In contrast, the Riksbank appears to have deviated from its mandate, but favorable circumstances contributed to an economic outcome with better performance than might have been expected based on policy choices.

What broader conclusions can be drawn from these examples of practical monetary policy? One is that a simple and transparent monetary policy framework has great benefits. The dual mandate of the Federal Reserve and the flexible inflation targeting of the Riksbank provide such frameworks. Both boil down to "forecast targeting," that is, setting the policy rate and choosing a policy rate path (and managing the central bank's balance sheet) so as to best stabilize the forecast of inflation around the inflation objective and the forecast of resource utilization around a sustainable level. For the framework to be more precise and operational, an inflation index, a measure of resource utilization, and a measure of stability need to be specified. It is important not to confuse measures of resource utilization that are to be used as indicators of inflationary pressures with those that are to be used as target variables. For the latter purpose, the gap between the actual and the sustainable unemployment rate seems more relevant, reliable, and transparent than the alternatives. I am convinced that the framework is more effective if only one inflation index and only one measure of resource utilization are chosen. When multiple measures are used, the framework becomes more opaque and accountability becomes difficult to enforce: policymakers can often find at least one or two that are close to the desired level and thus can motivate quite different policies.

Such a simple and transparent framework is a great help to policymakers in making the right decision and motivating this decision. Publishing the central bank's forecasts of inflation and resource utilization also makes external evaluation easier and more effective and makes it possible to hold powerful and independent policymakers accountable for their decisions. The present assessment of Federal Reserve and Riksbank monetary policy could not have been written without the public availability of their forecasts.

Finally, I remain quite suspicious of arguments that a lack of instruments, doubts about policy ineffectiveness, or other concerns are reasons why one should not try to best stabilize the forecasts of inflation and resource utilization around their desired levels. Such arguments often seem too vague and lacking in substance to be convincing.

ACKNOWLEDGMENTS The views expressed here are my own and are not necessarily shared by the other members of the Riksbank's Executive Board or the Riksbank's staff. I am grateful for helpful comments from and discussions with Hanna Armelius, Claes Berg, Alan Blinder, Bernard Dumas, Karolina Ekholm, Jon Faust, Martin Flodén, Gabriela Guibourg, Jesper Hansson, Donald Kohn, Stefan Laséen, Andrew Levin, Jesper Lindé, Edward Nelson, Bengt Pettersson, Raghuram Rajan, Ulf Söderström, Ingvar Strid, Staffan Viotti, Karl Walentin, Jonathan Wright, Janet Yellen, my discussants Randall Kroszner and David Wessel and other participants in the Brookings Papers conference, and the editors. I thank, without implication, Riksbank staff members Magnus Åhl, Björn Andersson, and Mikael Apel for contributions to the paper. From May 2007, I serve a 6-year term as deputy governor of the Riksbank and one of the six members of the Riksbank's Executive Board. 


\section{References}

Adrian, Tobias, and Hyun Song Shin. 2011. "Financial Intermediation and Monetary Economics." In Handbook of Monetary Economics, vol. 3A, edited by Benjamin M. Friedman and Michael Woodford, chapter 12. Amsterdam.

Apel, Mikael., Jan Hansen, and Hans Lindberg. 1996. "Potential Output and Output Gap.” Sveriges Riksbank Quarterly Review 1996:3: 24-35.

Assenmacher-Wesche, Katrin, and Stefan Gerlach. 2010. "Monetary Policy and Financial Imbalances: Facts and Fiction." Economic Policy (July): 437-82.

Baumeister, Christiane, and Luca Benati. 2010. "Unconventional Monetary Policy and the Great Recession-Estimating the Impact of a Compression in the Yield Spread at The Zero Lower Bound.” European Central Bank Working Paper no. 1258. Frankfurt: European Central Bank. Bernanke, Ben S. 2010a. "The Economic Outlook and Monetary Policy." Speech at the Federal Reserve Bank of Kansas City Economic Symposium, Jackson Hole, Wyo., August 27. . 2010b. "Monetary Policy Objectives and Tools in a Low-Inflation Environment." Speech at the Revisiting Monetary Policy in a Low-Inflation Environment Conference, Federal Reserve Bank of Boston, October 15. . 2011a. "Semiannual Monetary Policy Report to the Congress," testimony before the Committee on Financial Services, U.S. House of Representatives, July 13. .2011b. "Transcript of Chairman Bernanke's Press Conference, April 27, 2011." Washington: Federal Reserve Board. . 2011c. "Transcript of Chairman Bernanke's Press Conference, June 22, 2011." Washington: Federal Reserve Board. .2011c. "The Effects of the Great Recession on Central Bank Doctrine and Practice." Speech at the 56th Economic Conference, Federal Reserve Bank of Boston, October 18.

Blanchard, Olivier, and Jordi Galí. 2010. "Labor Markets and Monetary Policy: A New Keynesian Model with Unemployment.” American Economic Journal: Macroeconomics 2 (April 2010): 1-30.

Chung, Hess, Jean-Philippe Laforte, David Reifschneider, and John C. Williams. 2011. "Have We Underestimated the Likelihood and Severity of Zero Lower Bound Events?" Working Paper no. 2011-01. Federal Reserve Bank of San Francisco (January).

Claussen, Carl Andreas, and Øistein Røisland. 2010. "The Discursive Dilemma in Monetary Policy." Working Paper no. 240. Stockholm: Sveriges Riksbank.

Cúrdia, Vasco, and Andrea Ferrero. 2011. "How Much Will the Second Round of Large-Scale Asset Purchases Affect Inflation and Unemployment?” Liberty Street Economics (blog), Federal Reserve Bank of New York (May). http://libertystreeteconomics.newyorkfed.org/2011/05/how- 
much-will-the-second-round-of-large-scale-asset-purchases-affect-inflation-andunemployment.html.

D’Amico, Stefania, William English, David López-Salido, and Edward Nelson. 2011. "The Federal Reserve's Large-Scale Asset Purchase Programs: Rationale and Effects.” Working paper. Washington: Federal Reserve Board.

D’Amico, Stefania, and Thomas B. King. 2011. "Flow and Stock Effects of Large-Scale Treasury Purchases." Finance and Economics Discussion Series no. 2010-52, revised. Washington: Federal Reserve Board (April).

Diamond, Douglas W., and Raghuram G. Rajan. 2011. "Illiquid Banks, Financial Stability, and Interest Rate Policy." Working paper. University of Chicago.

Evans, Charles L. 2011. “The Fed's Dual Mandate Responsibilities and Challenges Facing U.S. Monetary Policy." Speech at the European Economics and Financial Centre, London, September 7.

Federal Open Market Committee. 2010a. "Press Release.” Washington: Federal Reserve Board (June 23). . 2010b. "Summary of Economic Projections.” Washington: Federal Reserve Board (June). . 2011a. "Minutes of the Federal Open Market Committee, June 21-22, 2011.” Washington: Federal Reserve Board. . 2011b. "Statement." (June 22). Washington: Federal Reserve Board. .2011c. "Summary of Economic Projections." Washington: Federal Reserve Board (June).

Finansinspektionen. 2010. "Den svenska bolånemarknaden och bankernas kreditgivning” [The Swedish mortgage market and the banks' granting of credit]. Stockholm (February).

Forslund, Anders. 2008. "Den svenska jämviktsarbetslösheten—en översikt” [The Swedish equilibrium unemployment rate - an overview]. Report to the Swedish Fiscal Policy Council. Stockholm: Finanspolitiska Rådet.

Fuhrer, Jeffrey C., and Giovanni P. Olivei. 2011. "The Estimated Macroeconomic Effects of the Federal Reserve's Large-Scale Treasury Purchase Program.” Public Policy Briefs no. 11-2. Federal Reserve Bank of Boston.

Gagnon, Joseph, Matthew Raskin, Julie Remache, and Brian P. Sack. 2011. "Large-Scale Asset Purchases by the Federal Reserve: Did They Work?” Federal Reserve Bank of New York Economic Policy Review 17 (May): 41-59.

Hamilton, James D., and Jing Cynthia Wu. 2011. “The Effectiveness of Alternative Monetary Policy Tools in a Zero Lower Bound Environment.” Working Paper no. 16956. Cambridge, Mass.: National Bureau of Economic Research (April; also forthcoming in Journal of Money, Credit and Banking). 
Kohn, Donald L. 2006. "Monetary Policy and Asset Prices.” Speech at "Monetary Policy: A Journey from

Theory to Practice," a European Central Bank Colloquium held in honor of Otmar Issing, Frankfurt, March 16.

. 2008. "Monetary Policy and Asset Prices Revisited." Speech at the Cato Institute's 26th

Annual Monetary Policy Conference, Washington, November 19.

. 2011. "Oral Evidence.” Presented to the Treasury Committee, U.K. House of Commons, May

17.

. Forthcoming. "John Taylor Rules." From the Great Moderation to the Great Deviation: A

Round-Trip Journey Based on the Work of John B. Taylor, edited by Evan Koenig and Robert

Leeson. Stanford, Calif.: Hoover Institution Press.

Krishnamurthy, Arvind, and Annette Vissing-Jorgensen. 2011. "The Effects of Quantitative Easing on

Interest Rates.” Working paper. Kellogg School of Management, Northwestern University (June).

Ministry of Finance. 2011. "Hur ska utvecklingen av arbetsmarknadens funktionssätt bedömas?” [How to

assess the development of the labor market's way of functioning?] Report from the Economic

Department. Stockholm. www.sweden.gov.se/sb/d/2062.

National Institute of Economic Research. 2010. The Swedish Economy June 2010. Stockholm. . 2011a. The Swedish Economy March 2011. Stockholm.

. 2011b. Wage Formation in Sweden 2011. Stockholm.

Posen, Adam S. 2011. "Not that '70's Show: Why Stagflation is Unlikely." Speech at the University of Aberdeen Business School, June 27.

Qvigstad, Jan F. 2005. "When Does an Interest Rate Path 'Look Good'? Criteria for an Appropriate Future Interest Rate Path-A Practician’s Approach.” Norges Bank Staff Memo no. 5/06. Oslo.

Reis, Ricardo. 2009. “Interpreting the Unconventional U.S. Monetary Policy of 2007-09.” BPEA (Fall): $119-65$.

Rudebusch, Glenn. 2011. “The Fed's Interest Rate Risk.” Federal Reserve Bank of San Francisco Economic Letter 2011-11, www.frbsf.org.

Svensson, Lars E. O. 2001. "The Zero Bound in an Open Economy: A Foolproof Way of Escaping from a Liquidity Trap.” Monetary and Economic Studies 19, no. S-1: (February): 277-312.

. 2004. "Commentary" (on Laurence H. Meyer, "Practical Problems and Obstacles to Inflation Targeting”), Federal Reserve Bank of St. Louis Review 84(4) (July/August): 161-164. . 2010a. "Policy Expectations and Policy Evaluations: The Role of Transparency and Communication." Sveriges Riksbank Economic Review no. 1: 43-78.

. 2010b. "Some Problems with Swedish Monetary Policy and Possible Solutions." Speech at the Fastighetsvärlden conference, Stockholm, November 24. 
. 2011a. "For a Better Monetary Policy: Focus on Inflation and Unemployment." Speech at Luleå University of Technology, Luleå, Sweden, March 8.

. 2011b. "Inflation Targeting." In Handbook of Monetary Economics, vol. 3B, edited by

Benjamin M. Friedman and Michael Woodford, chapter 22. Amsterdam: Elsevier.

. Forthcoming. "Evaluating Monetary Policy." In From the Great Moderation to the Great

Deviation: A Round-Trip Journey Based on the Work of John B. Taylor, edited by Evan Koenig and Robert Leeson. Hoover Institution Press.

Sveriges Riksbank. 2010a. Financial Stability Report 2010:2. Stockholm. . 2010b. "Minutes of the Executive Board's Policy Meeting," no. 3. Stockholm (June 30). . 2010c. "Minutes of the Executive Board's Policy Meeting," no. 5. Stockholm (October 25). . 2010d. Monetary Policy in Sweden. Stockholm (June).

. 2011a. "Minutes of the Executive Board's Policy Meeting," no. 3. Stockholm (July 4).

. 2011b. "Repo Rate Raised by 0.25 Percentage Points to 2.0 Per Cent." Stockholm (July 5). . 2011c. Material for Assessing Monetary Policy 2010. Stockholm . . 2011d. The Riksbank’s Inquiry into the Risks in the Swedish Housing Market. Stockholm.

Swanson, Eric T. 2011. "Let's Twist Again: A High-Frequency Event-Study Analysis of Operation Twist and Its Implications for QE2.” BPEA (Spring): 151-88.

Woodford, Michael. 2007. "The Case for Forecast Targeting as a Monetary Policy Strategy." Journal of Economic Perspectives 21, no. 4: 3-24.

Wright, Jonathan H. 2011. "What Does Monetary Policy Do to Long-Term Interest Rates at the Zero Lower Bound?” Working Paper no. 17154. Cambridge, Mass.: National Bureau of Economic Research.

Yellen, Janet L. 2011a. “Assessing Potential Financial Imbalances in an Era of Accommodative Monetary Policy." Speech at the 2011 International Conference: Real and Financial Linkage and Monetary Policy, Bank of Japan, Tokyo, June 1.

. 2011b. "The Federal Reserve's Asset Purchase Program.” Speech at the Allied Social Science Associations Annual Meeting, Denver, January 8.

. 2011c. "Unconventional Monetary Policy and Central Bank Communications." Speech at the University of Chicago Booth School of Business U.S. Monetary Policy Forum, New York, February 25.

\footnotetext{
* A previous version of this paper was prepared for the Fall 2011 issue of Brookings Papers on Economic Activity.
} 
${ }^{1}$ The reference to Pippi Longstocking (a fictional character, known for her unusual strength, in children's books by the Swedish author Astrid Lindgren) was made by OECD Secretary-General Angel Gurría in a speech on January 20, 2011. References to a tiger economy were, according to media reports, made by the British Chancellor of the Exchequer George Osborne and Swedish Minister of Finance Anders Borg.

${ }^{2}$ For instance, until January 2012 the Federal Reserve's mandate-consistent inflation rate had to be inferred from the Federal Open Market Committee participants' longer-term inflation forecasts, whereas the Riksbank has an explicit inflation target; the Federal Reserve's Greenbook and Bluebook (now replaced by the Tealbook) are published with a 5-year lag, whereas the Riksbank publishes an extensive Monetary Policy Report or a shorter Monetary Policy Update (both of which also include a policy rate path) after each policy meeting; and the Federal Reserve's minutes are nonattributed but attributed transcripts are published with a 5-year lag, whereas the Riksbank's minutes are attributed. In January 2012, the Federal Reserve announced an inflation objective of 2 percent and published policy path charts.

${ }^{3}$ Kohn (2007), Svensson (2011c), and Woodford (2007) explain why forecast targeting is both a better way of conducting policy and a better description of actual policy than following an instrument rule such as the Taylor rule.

${ }^{4}$ Being a central banker, in line with central bank custom I will refrain from commenting on the current and prospective policies of other central banks and therefore refrain from commenting on Federal Reserve policy in the summer of 2011 and later.

${ }^{5}$ Online appendixes for papers in this volume may be found on the Brookings Papers webpage at http://www.brookings.edu/economics/bpea.aspx. Those for this paper may also be found at the author's website, www.larseosvensson.net.

${ }^{6}$ In response to a question about an explicit inflation target for the Federal Reserve at the press conference on June 22, 2011, Chairman Bernanke explained why an inflation target is consistent with the Federal Reserve's mandate (Bernanke 2011c, pp. 9-10).

${ }^{7}$ As expressed in Sveriges Riksbank (2010d, p. 5), "the Riksbank, in addition to stabilising inflation around the inflation target, [is] also striving to stabilise production and employment around long-term sustainable paths." This sentence is followed by the sentence "This does not mean that the Riksbank neglects the fact that the inflation target is the overriding objective," in line with the Riksbank's "hierarchical" mandate (consistent with the statutes of the European System of Central Banks) that makes price stability the primary objective of monetary policy. As discussed in Svensson (2004), there is no fundamental difference between the Riksbank's hierarchical and the Federal

Reserve's dual mandate, once we distinguish first and second moments, that is, means and variances. The hierarchical mandate applies to the first moment, the unconditional mean. When it comes to the first moment, there is an explicit inflation target (an inflation rate of 2 percent per year) that is chosen and enforced by the Riksbank. There is no explicit target that is chosen for resource utilization. Instead, what is the highest sustainable resource utilization is determined by the properties of the economy and structural policies and is estimated by the Riksbank. Thus, the Riksbank has an independently chosen target for inflation but no independently chosen target for resource utilization. For the second moments, the variability of inflation and resource utilization, the Riksbank has a dual mandate in that it aims to stabilize both inflation around the chosen target and resource utilization around the estimated highest sustainable level.

${ }^{8}$ If the forecast is not close to its target or sustainable level at the end of the forecast period, the horizon of the mean squared gap can be extended, using any information about the forecast beyond the forecast horizon or by assuming a gradual return to the target or sustainable level. For details on mean squared gaps, see Svensson (2011c).

9 Several years ago, when I was still a big fan of the output gap, I had a discussion with Alan Blinder about which of the many concepts of potential output was most suitable. He strongly recommended the unemployment gap instead, on the grounds of simplicity and smaller measurement errors. I have obviously come around to his view.

${ }^{10}$ Blanchard and Galí (2010) examine a New Keynesian model with labor-market frictions, unemployment, and realwage rigidity. They derive a quadratic approximation to the welfare of a representative household and show that the relevant unemployment gap is the gap between the unemployment rate and the sustainable unemployment rate (the steady-state unemployment rate). They also derive a Phillips curve where the short-run NAIRU (the unemployment rate that implies constant inflation) differs from the sustainable unemployment rate.

${ }^{11}$ The "participants" at FOMC meetings are all the members of the Board of Governors and all the Federal Reserve Bank presidents. The "members" are the voting participants only. One might argue that the relevant forecasts are those of the voters only, but their separate forecasts are not available. The majority projections for growth, inflation, and unemployment need not always be consistent with the majority projection for monetary policy; see Claussen and Røisland (2010). Here I abstract from such "discursive dilemmas." 
${ }^{12}$ In recent years, large changes in the Riksbank's policy rates have led to large differences between the CPI, which includes the effect of varying mortgage rates on housing costs, and the CPIF, which does not. Most Executive Board members therefore consider stabilizing CPIF inflation to be more relevant under current circumstances, and the Riksbank has communicated this.

${ }^{13}$ Appropriately calibrated, more expansionary policy could have shifted the early part of the Riksbank forecast up toward the target without overshooting at the end of the forecast period. Even if there were some overshooting at the end of the forecast period and beyond, this would affect the mean squared gap very little, since the forecast would still be close to the target.

${ }^{14}$ This could be rounded to 5 , using unbiased rounding, but all projections outside this interval are above the interval. Therefore, I here depart from unbiased rounding and round the median and the sustainable unemployment rate up to 5.1 percent.

${ }^{15}$ Ekholm's dissent cited "the increased uncertainty prevailing as regards the sovereign debt problems in the euro area... [and] the relatively low inflationary pressure."

In my dissent I "advocated a repo-rate path with a repo rate of 0.25 per cent through the fourth quarter of 2010, and thereafter a gradual return to the repo-rate path of the main scenario" on the grounds that "such a repo-rate path results in a better outcome for both resource utilisation and inflation, with both lower unemployment and CPIF inflation closer to the target."

${ }^{16}$ According to the minutes of the December 2011 meeting, the FOMC will at the January 2012 meeting start publishing information about participants' projections of the appropriate level of the target federal funds rate and as well as qualitative information regarding participants' expectations for the Federal Reserve's balance sheet.

${ }^{17}$ In September 2011 the FOMC introduced a new Operation Twist, in which purchases of longer-maturity bonds are financed not by increased reserves but by sales of shorter-maturity Treasury bills and bonds, keeping the overall balance sheet constant. See Swanson (2011) on the original Operation Twist.

${ }^{18}$ The Riksbank is unique, as far as I know, in having detailed attributed minutes (since the June 2007 meeting, my first policy meeting), so it is possible to identify board members with the different arguments. This is not done here.

${ }^{19}$ The revision argument is further discussed in Svensson (2010b).

${ }^{20}$ See Sveriges Riksbank (2010a, 2011d) and Finansinspektionen (2010).

${ }^{21}$ See Svensson (2010b) and Sveriges Riksbank (2010a, 2011d) and more recent Financial Stability Reports for further details.

${ }^{22}$ See Assenmacher-Wesche and Gerlach (2010), Sveriges Riksbank (2011d), and references cited in Svensson (2010b).

${ }^{23}$ There is a general point about conditional forecasts that some think is trivial while others think it is not (see online appendix A4 for a detailed example). With a longer horizon, the conditional forecast approaches the unconditional mean. This means that the unconditional variance of the conditional forecast falls towards zero as the horizon increases. In contrast, the conditional variance of the outcome (which is the same as the conditional variance of the forecast error) rises toward the unconditional variance as the horizon increases. Thus, a lack of information beyond a certain horizon just shows up in the conditional forecast being closer to the unconditional mean. I find that this insight helps a lot. Much of the debate about the forecast is about how much relevant information we have. In practice, policymakers normally have very little information beyond the forecast horizon, in particular about the impact of the policy rate on the outcome. This means that we should be wary of acting on information that we do not have (about tail risk that is unrelated - or loosely related - to the policy rate, say). But we should still do the best we can with the information we have (and try to get more useful information if possible).

${ }^{24}$ Plots of commercial banks' leverage against the policy rate show no systematic relation between leverage and the policy rate.

${ }^{25}$ Furthermore, the optimal adjustment of risk when real rates of return fall depends on the precise preferences for expected real rates of return and risk, as is revealed by the simplest mean-variance analysis when the investment line is shifted down. "Search for yield" regardless of the risk is difficult to understand in such mean-variance analysis, other than as the result of an unfortunate and ill-conceived unconditional promise of a particular rate of return, which regulators should prohibit.

${ }^{26}$ Adrian and Shin (2011) and Diamond and Rajan (2011) also do not contain the frictions, such as sticky prices, that allow meaningful modeling of the effects of monetary policy.

${ }^{27}$ Yet another argument, which I do not discuss below, is that tight money is not the problem for the U.S. economy, and therefore easier policy is not the solution. I fail to understand this argument. If the economy is affected by negative shocks independent of monetary policy, it seems that easier monetary policy would remedy the situation, if 
easier policy is possible. The best thing would be to directly undo the negative shocks, but if this is not possible, easier monetary policy is an obvious second best.

${ }^{28}$ Calvo-style price-setting firms are assumed to index prices to $\pi^{*}$ when not setting the optimal price.

${ }^{29}$ Note that equation 2 incorporates the central bank's forecast of private sector inflation expectations, $\pi_{t+\tau+1 \mid t+\tau, t}$, as

a separate variable. This means that private sector inflation expectations need not be assumed to be rational, and the central bank's forecast for private sector inflation expectations can differ from its forecast for inflation. In the special case of rational expectations and symmetric information, the Phillips curve can be solved forward, private sector inflation expectations are endogenous and equal to the central bank forecast, and the inflation forecast depends only on the forecast or expectations of the output gap and the cost-push shock.

${ }^{30}$ See, for example, Baumeister and Benati (2010), Chung and others (2011), D'Amico and others (2011), D'Amico and King (2011), Cúrdia and Ferrero (2011), Fuhrer and Olivei (2011), Gagnon, Raskin and Remache (2011), Hamilton and Wu (2011), Krishnamurthy and Vissing-Jorgensen (2011), Swanson (2011), and Wright (2011).

${ }^{31}$ See Chung and others (2011, figure 10), for an estimate of the separate effect of QE2 ("phase 3").

${ }^{32}$ In the June 2011 minutes (FOMC 2011a), the FOMC provided the following clarification: "In the discussion of inflation in the statement, members decided to reference inflation - meaning overall inflation - rather than underlying inflation or inflation trends, in order to be clear that the Committee's objective is the level of overall inflation in the medium term." This indicates that the FOMC puts little weight on developments of PCE inflation in the short term.

${ }^{33}$ The median of the participants' projection of the longer-run unemployment rate falls in the interval 5.35 to 5.55 percent, with a midpoint of 5.45 percent (FOMC 2011c). I round this to 5.4 percent. [Is there a reason you broke from the standard here and didn't round to 5.5? LS: Unless there is a special reason, I round to the nearest even number. Always rounding up introduces a (small) bias.]

${ }^{34}$ Estimates of the sustainable unemployment rate are included in the longer Swedish versions of the publications.

${ }^{35}$ In August 2011, after the outlook had deteriorated significantly during the summer, the FOMC increased the extended period and announced that it anticipated that economic conditions were likely to warrant exceptionally low levels for the federal funds rate at least through mid-2013. In September 2011 it introduced a new Operation Twist.

${ }^{36}$ As stated in the press release (Sveriges Riksbank 2011b), we "preferred a repo rate equal to 1.75 per cent and a repo rate path that first rises slowly to 2 per cent in the third quarter of 2012 and then rises faster to about 3.8 per cent by the end of the forecast period. This is motivated by [our] assessment that the Report's forecasts for foreign policy rates and Swedish resource utilization are both too high. [Our] repo rate path would imply CPIF inflation closer to 2 per cent and a faster reduction of unemployment towards a longer-run sustainable rate." Online appendix A8 provides more details on why we preferred that path.

${ }^{37}$ The implied forward rates have been adjusted by a forward term premium of one basis point per month. The curves have been extended beyond the standard three-year horizon by me.

${ }^{38}$ In figure 4, compare the large gap between 2007Q4 GDP and potential GPD as of June/July 2010 with the small gap between the 2007Q4 GDP and potential GDP as of September 2008.

${ }^{39}$ Recall that expected future short rates equal the forward rate less the forward term premium. Thus, with normal positive forward term premiums (such as the standard $1 \mathrm{bp}$ per month), market expectations of future short rates are a bit below the forward rate curve. When forward term premiums vary and are substantial, one needs to treat market expectations of future short rates and the term structure of interest rates separately. 